\title{
Liquidity Management and Corporate Investment During a Financial Crisis*
}

\author{
Murillo Campello \\ University of Illinois \\ \&) NBER \\ campello@illinois.edu \\ John R. Graham \\ Duke University \\ \& $N B E R$ \\ john.graham@duke.edu
}

\author{
Erasmo Giambona \\ University of Amsterdam \\ e.giambona@uva.nl
}
Campbell R. Harvey
Duke University
\& $N B E R$

cam.harvey@duke.edu

This Draft: October 12, 2010

Key words: Financial crisis, liquidity management, investment spending, credit lines, drawdown activity, cash savings.

JEL classification: G31, G32.

*Corresponding author: Campbell R. Harvey, Fuqua School of Business, Duke University, Durham, NC 27708-0120. E-mail: cam.harvey@duke.edu. We thank James Choi, Enrica Detragiache, Jean Helwege, Matt Spiegel (the editor), Ilya Strebulaev, Amir Sufi, Yongjun Tang, and two anonymous referees for their suggestions. We also benefited from comments from seminar participants at the ECB/CFS Conference (2009), FIRS Conference (2010), Global Issues in Accounting Conference (2010), RFS/Yale Financial Crisis Conference (2009), University of Amsterdam, University of Bologna, and WFA Meetings (2010). We thank CFO Magazine for helping us conduct the surveys, though we note that our analysis and conclusions do not necessarily reflect those of $C F O$. We thank Benjamin Ee and Hyunseob Kim for excellent research assistance. 


\title{
Liquidity Management and Corporate Investment During a Financial Crisis
}

\begin{abstract}
This paper uses a unique dataset to study how firms managed liquidity during the 2008-09 financial crisis. Our analysis provides new insights on interactions between internal liquidity, external funds, and real corporate decisions, such as investment and employment. We first describe how companies used credit lines during the crisis (access, size of facilities, and drawdown activity), the characteristics of these facilities (fees, markups, maturity, and collateral), and whether managers had difficulties in renewing or initiating lines. We also describe the dynamics of credit line violations and the outcome of subsequent renegotiations. We show how companies substitute between credit lines and internal liquidity (cash and profits) when facing a severe credit shortage. Looking at real-side decisions, we find that credit lines are associated with greater spending when companies are not cash-strapped. Firms with limited access to credit lines, on the other hand, appear to choose between saving and investing during the crisis. Our evidence indicates that credit lines eased the impact of the financial crisis on corporate spending.
\end{abstract}

Key words: Financial crisis, liquidity management, investment spending, credit lines, drawdown activity, cash savings.

JEL classification: G31, G32. 
In the spring of 2009, world financial markets were in the midst of a credit crisis of historic proportions. While unfortunate, the crisis environment created an opportunity to draw crisp inferences about corporate behavior. In this paper, we study interactions between internal and external sources of liquidity and show how those interactions affect companies' decisions regarding capital investment, technology spending, and employment. While prior research has looked at the impact of cash and profits on firm behavior, we consider an additional source of liquidity: lines of credit.

Companies rely extensively on credit lines provided by banks (see Shockley and Thakor (1997)). Contemporary papers document increased corporate use of credit lines during the financial crisis (Ivashina and Scharfstein (2010) and Campello et al. (2010)). Others shed light on the relation between credit lines and cash (Lins et al. (2010)) or profitability (Sufi (2009)). In contrast, our paper examines how firms choose between different sources of liquidity when liquidity is scarce. Our paper is the first to study during a credit crisis the demand for credit lines, the costs associated with credit lines, the ease with which firms are able to initiate or renew lines, the consequences of violating a credit line covenant, the outcomes of renegotiation after violations, and how firms manage liquidity coming (concurrently) from credit lines, cash holdings, and profits. Notably, our study also provides new insight into the relation between liquidity management and real expenditures during the crisis.

To learn how firms manage liquidity and investment when liquidity is scarce, in early 2009 we surveyed 800 CFOs from North America, Europe, and Asia, asking about their cash holdings, profits, access to bank credit lines, use of available lines, the costs associated with credit lines, and their pro forma plans regarding investment, technology, and employment expenditures. ${ }^{1}$ In contrast to studies of observed (ex-post) outcomes based on archival data, our survey approach allows us to examine firms' planned (ex-ante) policies and the relations between liquidity and real decisions. In this way, we study decisions that are not contaminated by events that may co-determine observed corporate behavior but that were not part of managers' information sets when they formulated their policies (such as the outcomes of governmental programs put in place to address the crisis). Our approach allows us to establish clear, timely links between credit availability and firms' financial and real decisions.

Detailed data on credit lines are not available from standard commercial databases. COMPU- 
STAT, for example, does not have this information, and LPC-Dealscan only has originations (not balances), and even then only for larger firms and banks. Archival data sources are unlikely to have information on companies' difficulties in renewing a line, much less on deals that did not go through. In addition, these sources do not provide detail on loan covenant violations or line renegotiations. Our survey instrument yields new data on all of these dimensions. These data describe the determinants of credit lines (size of facilities), the use of available credit lines (drawdowns), the maturity and costs of those facilities (commitment fees, interest spreads, use of collateral), the frequency and reasons for covenant violations, the consequences of violations, the outcomes of renegotiations, and the interactions between credit lines and other sources of internal liquidity (cash holdings and cash flows) during the crisis. In contrast to most papers, we gather information from both public and private firms. Our data yield new evidence on the use and cost of external liquidity during the financial crisis, showing how firms substitute between internal and external funds in that period.

We first study how firms managed their credit lines during the crisis. Firms that are small, private, non-investment grade, and unprofitable had significantly higher lines-to-asset ratios than their larger, public, investment grade, profitable counterparts, both in 2008 and in 2009. Our data show that the first set of firms drew significantly larger amounts of funds under their line facilities during the crisis. For example, private firms drew, on average, $42 \%$ of the total funds in their lines in 2009 , compared to only $26 \%$ for public firms. Univariate tests also uncover a negative correlation between credit lines and cash balances.

Next, we examine how companies' cash and profitability affect the use of credit lines (size of facilities and drawdown activity). We do so using an interactive regression model. For a firm with little or no cash, a one-interquartile range (IQR) increase in cash flows is associated with an increase of $4 \%$ in the ratio of credit lines-to-total assets (the sample average ratio is $24 \%$ ). However, the positive association between cash flow and credit lines becomes weak as firms hold more cash. At the ninth decile of cash holdings, for example, a one-IQR change in cash flow does not affect credit lines. Our tests thus show that higher cash flows need not lead to increases in the size of credit lines. More generally, they point to a substitution effect between internal and external sources of liquidity during the crisis. 
One of the advantages of our data is that we can study line drawdown activity. Firms with higher cash flows drew fewer funds from their credit lines, as did firms with more cash on hand. In other words, conditional on having a line, cash flows and cash holdings both lead to smaller drawdowns. Our drawdown results are also consistent with a substitution between internal and external liquidity during the crisis. Notably, different from tests that are based on the size of credit lines, the drawdown tests are not subject to a reverse-causality critique: smaller drawdowns cannot cause the firm to have more cash in hand.

Our findings indicate that firms choose not to use credit lines when they have enough internal funds, implying a cost wedge between these two sources of liquidity. It is thus important that we understand how lines are priced during the crisis. To investigate this issue, in a subsequent survey (conducted in the second quarter of 2009) we gather data on the pricing of credit line facilities (both during that quarter as well as in the second quarter of 2008). While it is not surprising that credit facilities became generally more costly, we are able to identify and characterize heterogeneity across firms. In the U.S., commitment fees increased by 14 basis points on average (i.e., nearly doubled) over the crisis. For small, private, non-investment grade, unprofitable borrowers, average markups over LIBOR/Prime increased between 70 and 95 basis points, and the average line maturity declined by about 3 months (down from 26 months in early 2008). Other borrowers observed less pronounced changes in the pricing of their lines. We also find that firms with more internal liquidity were less likely to pay a commitment fee (extensive margin), and that, conditional on paying a fee, they paid lower fees (intensive margin). In other words, firms with more internal funds could access lines of credit at a lower cost, yet they borrowed less from those facilities.

We also gather data on violations of credit line covenants and on outcomes of subsequent renegotiations. We show, for example, that a relatively small fraction of firms (10\%) have their lines canceled upon violating covenants in the crisis. At the same time, about two-thirds of violators are able to renegotiate the terms of their lines. Nearly $70 \%$ of those who renegotiate report an increase in the cost of those lines (markups and fees). Line drawdown activity is also reduced after a violation.

The last part of our analysis examines the interplay between corporate liquidity and real-side poli- 
cies. Our data allow us to study liquidity coming from internal sources (cash holdings and cash flows) and an external source (credit lines) within an instrumental variables framework. To our knowledge, previous papers have not quantified connections between credit lines and real expenditures.

Our evidence suggests important interactions between a firm's internal liquidity, credit lines, and investment spending. At the average level of cash, an increase in credit lines does not alter a firm's investment plans. Cash-rich firms, in contrast, boost their investment as the size of their lines increases. For example, at the ninth decile of cash, a one-IQR increase in credit lines is associated with an increase of $3 \%$ in planned investment over the next year (the average planned investment rate is $-15 \%)$. We also document a tradeoff between cash saving and investment spending among firms with little or no access to credit lines: firms that save the most also plan the largest investment cuts. However, as credit lines increase, this relation is reversed. At the ninth decile of lines, a one-IQR increase in cash leads investment to grow by $3 \%$. Iin contrast, for a firm with no credit lines, investment drops by $5 \%$. We report similar evidence for technology spending and employment growth. In all, our estimates indicate an important interaction between credit lines and cash in terms of how either variable affects corporate spending during the crisis.

We offer a number of new insights relative to existing research. Ivashina and Scharfstein (2010) provide an early account of the effect of the financial crisis on bank lending. The authors describe a borrowers' "run" on outstanding bank credit facilities following the Lehman collapse. Their evidence shows that banks that co-syndicated more with Lehman experienced larger line drawdowns and cut lending by more. Campello et al. (2010) use a survey-based proxy to gauge the effects of financing constraints during the crisis. Their survey asks managers about firms' cash stocks and credit lines, but their paper provides no formal analysis of how these sources of liquidity relate to each other. Nor does their paper provide a quantitative assessment of how liquidity might affect investment; in particular, they do not have data on line drawdowns. As documented uniquely in this paper, drawdown activity is central to understanding how firms manage liquidity in the crisis. Another innovation of our paper is the description of the dynamics of covenant violations and credit line renegotiations in the crisis. Our paper deepens the understanding of liquidity management in the crisis and describes 
its relation to real-side decisions.

A recent paper by Lins et al. (2010) provides evidence on the relation between cash and credit lines. Those authors survey CFOs in 29 countries in 2005, asking about their firms' use of cash and lines. Lins et al. conclude that non-operational cash is used to hedge against negative cash flow shocks, while credit lines provide firms with the ability to exploit future business opportunities. Sufi (2009) studies the relation between cash flow and the choice between cash and credit lines. He shows that high cash flows are critical to satisfy loan covenants, allowing for greater use of credit lines by firms (relative to cash). Differently from our paper, both Lins et al.'s and Sufi's studies are conducted in a period of easier credit. ${ }^{2}$ We are able to test whether the dynamics change in a crisis period. In addition, we are able to examine the real-side implications of credit lines.

A common theme motivating a firm's demand for liquid assets is that those assets secure financing in states in which the firm may not have funds to pay its obligations or invest. This general idea underlies theories explaining corporate cash savings (e.g., Kim et al. (1998) and Almeida et al. (2004)) and theories explaining the use of credit lines (Boot et al. (1987), Holmstrom and Tirole (1998), and Thakor (1995)). Despite the similarities between the literatures on cash holdings and credit lines, there is no unifying theory describing the interplay of these two sources of liquidity. Existing theories, however, consider the importance of liquidity under contingencies in which credit is scarce (the context of our empirical examination). While our survey data do not allow us to thoroughly test and contrast the predictions of those theories, we believe our findings may generate interest in new

models linking firms' choices between internal and external liquidity, and their effect on investment. ${ }^{3}$

The remainder of the paper is organized as follows. We describe the data in the next section. Section 2 shows how firms manage different sources of internal liquidity (cash holdings and cash flows) as well as external liquidity (credit lines). Section 3 examines the interplay between liquidity management and real-side policies such as investment and employment. Section 4 concludes.

\section{Data}

We survey CFOs from 31 countries in North America, Europe, and Asia during a severe contraction in the supply of credit: the 2008-2009 financial crisis. To streamline our analysis, we only report and 
discuss results for our U.S. sample (397 non-financial, for-profit firms) in this paper, while Campello et al. (2011) examine the European data and draw similar conclusions. The crisis period is an interesting time to study liquidity and credit friction issues. We ask CFOs about their holdings of cash, their access to bank credit lines, their use of available lines, the cost of those credit facilities, and their pro forma plans about investment, technology, and employment.

To shorten the exposition, we present the details of the data gathering process in the Data Appendix. Our main survey is administered in the first quarter of 2009, when the financial crisis was in full swing. It contains questions pertaining to that period as well as one year before; that is, six months prior to the Lehman bankruptcy, which is considered by many the peak of the crisis. ${ }^{4}$ The appendix also provides a comparison between our sample and the standard COMPUSTAT data set. ${ }^{5}$ Before presenting the descriptive statistics, we discuss data limitations.

One concern is that we only have one cross-section of firms. Ideally, we would like to use firmfixed effects and analyze "within estimators." While this is not available to us, we have a number of variables that are measured in changes and other variables for which we have current and lagged values. For example, we ask managers about their cash-to-asset positions in early 2009 as well as their cash holdings one year before. We have similar information about credit lines. These data allow us to: (1) look at changes in cash holdings and credit lines from before to the peak of the crisis to the period following the peak, and (2) use lagged values for these variables as instruments in IV regressions. We also highlight caveats that apply to all empirical studies that are based on surveys. For instance, while we consulted with experts and refined our survey questions, it is still possible that some of the questions were misunderstood or otherwise produce noisy measures of the variables of interest. In addition, when interpreting field studies one needs to consider that market participants may not necessarily understand the reason they do what they do in order to make (close to) optimal decisions. Readers should bear these limitations in mind.

Table 1 reports descriptive statistics for our sample. The table presents variables reflecting liquidity management, a broad set of firm characteristics, and real-side policy variables including forward-looking capital investment, technology spending, and employment growth. The real variables measure the CFOs' planned percentage changes in these policies over the next 12 months. As expected, firms plan substantial cuts in expenditures. On average, firms plan to cut investments 
by about $15 \%$. Planned cuts in technology spending and employment are approximately $6 \%$ over the next 12 months. Managers are also asked to rate (on a 0 to 100 scale) their firms' long-term investment prospects and also rate their firms' access to credit.

TABLE 1 ABOUT HERE

Table 1 shows evidence of widespread use of credit lines; these facilities appear to be a critical source of liquidity for our sample firms. On average, credit lines represent about $24 \%$ of total assets, compared to $12 \%$ for cash holdings and $9 \%$ for cash flows. ${ }^{6}$ The table shows that only $22 \%$ of the companies in our sample are publicly listed. This is a unique feature of our data relative to other studies, which usually rely entirely on public firm data. About one-in-five of our firms have revenues greater than $\$ 1$ billion and three-in-ten have rated debt.

\section{Liquidity Management During the Crisis}

In this section, we study how firms manage liquidity during the crisis. We start with mean difference tests and correlation analyses. We then use regression analysis to differentiate between alternative explanations for how firms substitute between internal and external liquidity.

\subsection{Access to Credit Lines, Drawdowns, and Cash Holdings: Subsample Analysis}

We say that firms are "small," "private," "bank-dependent," "non-investment grade," have "limited access to credit," and are "unprofitable" if, respectively, their sales are less than $\$ 1$ billion, they are privately held, they do not have a credit rating, their bonds are unrated or rated below investment grade (BBB-), they rate themselves in the bottom three deciles for access to external funds during the crisis, and they reported losses in fiscal year $2008 .{ }^{7}$ The counterparts of the firm types just described are, respectively, "large," "public," "non-bank-dependent," "investment grade," "easy access to credit," and "profitable." For convenience, we denote these firms collectively as "regular borrowers."

\section{TABle 2 ABOUT HERE}

Table 2 reports mean comparison tests for credit lines and cash holdings over the crisis. Column 1 shows that access to a credit line facility is generally greater among firms in the regular borrower categories. These differences are statistically significant for the size, bank-dependence, reported credit 
access, and profitability partitions using a two-tail difference test. For instance, $92 \%$ of the large firms in our survey have credit lines, relative to only $75 \%$ of the small firms.

Column 2 reports the proportion of firms that have experienced difficulties in initiating or renewing a credit line during the crisis. We find that $23 \%$ of private firms experienced difficulty in obtaining or maintaining a line of credit, compared to $14 \%$ of public firms. Differences are even sharper between firms with limited access to credit versus those with easy access (41\% versus $3 \%$ ), or between unprofitable versus profitable firms (42\% versus 16\%). This analysis complements Sufi (2009), who shows that credit line access is conditional on the firm's financial health. We add to this by quantifying that in the midst of a severe credit contraction four-in-five of the respondent companies do not face difficulties in renewing a credit line. Later in the analysis, we use a multivariate framework to assess how firm characteristics affect the probability of facing difficulties in initiating or renewing a credit line.

Column 3 indicates that non-regular borrowers were disproportionately more likely to draw on their credit lines during the crisis. Considering the amount drawn, column 4 shows those firms drew down almost twice as much funds as their counterparts. For instance, the average private firm drew $42 \%$ of the funds under its credit facilities, compared to only $26 \%$ for the mean public firm. Firms that report limited access to credit and negative profits drew $54 \%$ and $64 \%$ of their credit line maximums, respectively. These findings parallel the results in Jimenez et al. (2009), who find that defaulting firms draw down more from their credit lines. Although we do not have information on eventual default, we find that unprofitable firms have a higher propensity to draw from their lines in the crisis and, on average, draw down more of the funds available under those lines.

Columns 5 and 6 show that lines-to-asset ratios declined only slightly from the first quarter of 2008 to the first quarter of 2009 . As we show later, while the quantity of lines available to firms seems to have declined only slightly, the terms of those facilities (fees, interest rates, maturity, collateral) changed significantly over the crisis. Our estimates also indicate that regular borrowers have smaller credit lines (relative to assets). Columns 7 and 8 show that corporate cash stocks declined between 2008 and 2009. Declines in cash are less pronounced among regular borrowers ( $t$-tests omitted).

It is worth highlighting the novelty of the results in Table 2. The various firm characteristics that we examine, for example, are absent from the work of Ivashina and Scharfstein (2010), who look at the drawdown activity of a select group of public firms (firms borrowing through Lehman 
syndicates). The empirical estimates we report also complement the work of Campello et al. (2010), who do not provide quantitative information on drawdown activity. Lins et al. (2010) examine data from 2005, a non-crisis period, and do not quantitatively analyze drawdown activity.

\subsection{Credit Lines and Cash Holdings: Univariate Analysis}

This section provides basic evidence on interactions between credit lines, drawdowns, and cash holdings. Table 3 reports correlations between these liquidity variables for early 2008 and 2009 (with the caveat that we do not have drawdowns for 2008). The table shows a negative correlation between credit lines and cash holdings in the crisis (statistically significant at the $10 \%$ level). Interestingly, the negative correlation between cash and credit lines is five times more negative following the peak of the crisis than in the period preceding it $(-0.11$ versus -0.02$)$. Table 3 also reveals a strong negative relation between cash holdings and drawdowns. These correlations are consistent with firms using credit lines and cash holdings as substitutes to manage liquidity, apparently more so as the crisis deepened. The table shows that drawdown proportions are positively correlated with the size of the facility.

\section{TABLE 3 ABOUT HERE}

We next compute the ratio of drawdowns to the sum of overall external funds (including drawdowns, equity issuances, debt issuances, and commercial paper issuances). Table 4 reports mean comparison tests conditioned on borrower characteristics. The estimates highlight a systematic pattern. The average drawdown-to-external funding ratio ranges from $23 \%$ to as high as $51 \%$ for firms that are small, private, non-investment grade, bank-dependent, and unprofitable. Within the regular borrower group, in contrast, the average drawdown ratio ranges from only $3 \%$ for public firms to $18 \%$ for profitable companies. Differences in drawdown-to-external funding ratios across these firm types are economically and statistically significant.

\section{TABLE 4 ABOUT HERE}

The correlations in Table 3 suggest that cash and credit lines are alternative (substitute) sources of liquidity. The mean comparison tests in Table 4 imply that firms actively used their credit lines

— they draw funds from these facilities — to deal with the crisis, particularly those firms that were not "regular borrowers" (that is, firms that did not have easy access to credit). While interesting, 
we consider the evidence from these univariate tests as suggestive only. Next, we use multivariate analyses to more fully characterize firms' liquidity management in the crisis.

\subsection{Credit Lines and Cash Holdings: Regression Analysis}

A regression approach has two main advantages for our investigation of liquidity management during the crisis. First, it allows us to check whether inferences are robust to multiple sources of firm heterogeneity (e.g., size or profitability). Second, it allows us to determine whether there are nonlinearities in the way cash flow and cash holdings interact in explaining the use of credit lines.

\subsubsection{Basic Models of Credit Lines}

We start in Table 5 with credit line models that can be compared with those in Sufi (2009). Panels A and B display models for the size of credit lines and drawdown activity, respectively. In columns 1 and 2 (both panels) we essentially estimate two of the main models reported in Table 3 of Sufi's paper. For comparability, in columns 1 and 2 of Panel A the dependent variable is the ratio of credit lines to the sum of lines of credit and cash holdings; while in Panel B it is the ratio of unused lines of credit to the sum of unused lines of credit and cash holdings. We regress lines of credit (alternatively, unused lines) on cash flow and several firm-specific measures, including long-term investment prospects (denoted Investment Growth Prospects), size (Large), credit ratings (Investment Grade), and ease of access to credit (Easy Credit). The specification can be written as follows:

$$
L C /(\text { LC }+ \text { CashHoldings })_{i}=c+\alpha_{1} \text { CashFlow }_{i}+\gamma \mathbf{X}_{i}+\varepsilon_{i},
$$

where $c$ is a constant, $\mathbf{X}$ is a matrix containing control variables, and $\varepsilon$ is an error term. Our regressions are estimated with heteroskedasticity-consistent errors clustered by industry (Rogers (1993)). ${ }^{8}$

\section{TABLE 5 ABOUT HERE}

We first split our sample between public and private firms (Sufi studies only public firms). Consistent with Sufi, in the public firm regressions of column 1 (Panels A and B) we find that cash flow enters the total lines and the unused lines models with a statistically positive coefficient. Economically, when cash flow moves from the first to the ninth decile $(=0.20)$, the ratio of lines of credit-to-total liquidity increases by 0.09 . Relative to the sample mean of 0.47 , this is equivalent to 
an increase of about $19 \%$, which is similar to the $15 \%$ figure that Sufi reports for his random sample of public firms. ${ }^{9}$ The statistical significance of our cash flow estimate is noteworthy given that we have a limited number of public firms in the regression. Coefficients for the control variables are also generally consistent with the Sufi's analysis, but are statistically weaker. Sufi concludes that more profitable firms use significantly more lines of credit than cash in their liquidity management because higher profits makes a firm less likely to violate covenants.

We do not find this same result in our sample of private firms, however. For private firms, profitability is not a major driver of the availability of credit lines (Panel A), nor does it affect the use of credit lines (Panel B). For these firms, the use of lines is determined by characteristics such as size, credit quality, and growth prospects. These results are new and relevant to the literature. Recall from Table 2 that private firms had more lines of credit (both frequency and ratio of lines to assets), were more likely to draw funds from their lines, and drew down more funds than public firms during the crisis. Private firms are also more bank-dependent. Our results thus imply that cash flows are not a main driver of credit line access or usage for those firms that are most likely to rely on credit lines for funding. The next set of tests more fully characterize the relation between cash flows and lines of credit.

\subsubsection{Interactive Models of Credit Lines}

The dependent variable in the previous model measures the importance of credit lines relative to cash. However, that specification does not differentiate between positive changes in lines of credit and negative changes in cash savings: when the ratio of credit lines to cash goes up, one cannot determine which of the different components of liquidity is increasing, declining, or staying constant. Additionally, the specification imposes a linear relation between cash flow and the lines-to-cash ratio. For example, it might be the case that cash flow helps a firm establish lines, and that at low levels of cash holdings the firm will use lines to finance its activities. However, at higher levels of cash, the same firm may not need to raise additional credit lines, even if it has large enough cash flows to sustain the new lines. These dynamics seem plausible, but they cannot be identified in a linear model specification that collapses the cash-credit lines trade-off in the dependent variable.

In columns 3 through 5 of Table 5 , the dependent variables are the ratio of credit lines to assets 
(Panel A) and the ratio of drawdowns to credit lines (Panel B). The right-hand side regressors include cash holdings as well as its interaction with cash flows. The advantage of this new specification is that it allows us to isolate changes in lines of credit (alternatively, drawdowns) from changes in cash holdings — the model no longer collapses cash into the denominator of the left-hand side variable. To disentangle the interplay between internal and external sources of liquidity, these tests allow for nonlinearities in the way cash flows and cash holdings interact in explaining lines of credit. Following previous notation (see Eq. (1)), the new line of credit model can be written as:

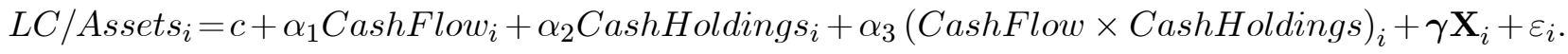

In column 3 of Panel A, we report results from regressing lines of credit on cash flows. ${ }^{10}$ Excluding cash holdings from the specification, we find that cash flows have a positive effect on the magnitude of lines of credit that a firm has available. In column 4, we add cash holdings and find a statistically negative relation between cash holdings and credit lines, confirming our intuition that firms trade off cash with credit lines. This strong, negative relation also highlights the need to include an explicit proxy for cash holdings in line of credit analysis. In column 5, we include cash flows, cash holdings, as well as their interaction in the set of regressors.

We focus on the full model of column 5. Given the interactive structure of this model, one must carefully interpret the economic meaning of the reported coefficients. The positive coefficient on cash flow suggests that profitability helps firms raise credit lines. At the same time, the negative coefficient on cash holdings implies that firms trade off credit lines with cash holdings. The significant negative interaction between cash holdings and cash flows delivers an even more interesting insight. Our estimates imply that, in a hypothetical situation in which a firm has little or no cash, a one-interquartile range $(\mathrm{IQR})$ change in cash flows $(=0.12)$ is associated with an increase of about $4 \%$ in the credit lines-to-total assets ratio (the sample average ratio is about 24\%). That is, in the absence of internal savings, cash flows increase the firm's access to credit lines. However, this dynamic is mitigated as cash savings increase. At the ninth decile of cash holdings $(=0.30)$, for example, a similar change in cash flow increases the use of credit lines by only $2 \%$. This $2 \%$ estimated effect is not statistically different from zero. In fact, we find that inferences about a positive impact 
of cash flows on credit lines are only statistically significant in samples of firms with relatively low cash (those in the first three deciles of the distribution of cash holdings). Figure 1 characterizes the economics of the interaction effects just discussed (see Panel A).

\section{FiguRE 1 ABOUT HERE}

Another way to characterize these effects is to look at the impact of a one-IQR increase in cash holdings $(=0.14)$ at the ninth decile of cash flows $(=0.25)$. We find that this change would lead a firm to reduce its credit lines by about $3.7 \%$ of total assets (see Figure 1, Panel B). At the average level of cash flow, the decline is $2.7 \%{ }^{11}$ That is, even taking into consideration that credit lines are made available to more profitable firms, we find that firms with relatively high internal liquidity use credit lines less intensively. Our specification is able to uniquely identify these dynamics because we study separate (and interactive) terms for cash holdings and credit lines.

Although we interpret our results in terms of how changes in cash affect credit lines, one could also interpret them as simply suggesting that firms will save cash in the crisis if they lack access to credit lines. The next set of tests removes this ambiguity about the direction of causality. Columns 3 through 5 of Panel B in Table 5 report drawdown regression results. We find that firms with higher cash flows and more cash savings draw fewer funds from their credit lines. These results are interesting because they are also consistent with a substitution between internal and external liquidity during the crisis. Moreover, they are not subject to a reverse-causality critique: fewer drawdowns from existing lines cannot cause the firm to have more cash in hand. We note, however, that the interaction term for cash flows and cash holdings is not statistically significant.

We also check whether our results hold outside of the crisis. To do so, we use data from Sufi (2009). ${ }^{12}$ Sufi's sample is comprised of a panel of 300 randomly selected public firms over the $1996-$ 2003 period. Column 6 (Panels A and B) replicates the specification of column 5 using Sufi's data, yielding largely similar results. Even in a non-crisis period, we find that cash flow has a positive effect on credit lines while cash has a negative effect. Notably, the interaction between those two variables indicates that more profitable firms use fewer credit lines when cash holdings are high. Our findings on the interplay between internal liquidity (profitability and cash reserves) and external liquidity (credit lines) thus generalize beyond the crisis period. 
The tests of this section are new and relevant in showing how firms manage various sources of liquidity when credit is scarce. Although our tests are related to recent empirical work on credit lines (e.g., Ivashina and Scharfstein (2010), Campello et al. (2010), Lins et al. (2010), and Sufi (2009)), to our knowledge, existing research does not describe the relations between cash holdings, cash flows, and lines of credit (including drawdowns) under similar economic circumstances. Insight into how companies respond to credit shocks is relevant for economic policy-making. Our results should also be of interest to future theoretical work on corporate liquidity management.

\subsection{Initiating and Renewing Credit Lines During the Crisis}

The tests of Section 2.3 show that internal savings (cash holdings) and operating performance (cash flows) affected companies' credit lines during the crisis. In this section we focus on whether savings and performance influenced the odds that a firm was able to initiate or renew a credit line in the crisis. Since the crisis led to a significant drop in corporate sales and liquidity, it is important to gauge the extent to which these effects may have affected corporate access to fresh bank financing.

In Table 6, we report the results from probit regressions where the dependent variable equals 1 if the firm reported difficulties in initiating or renewing a credit line during the crisis, and 0 otherwise. The independent variables are similar to those of Eq. (2). As one would expect, the estimates in the table imply, for example, that public firms are less likely to face difficulties in obtaining or maintaining credit lines (cf. Table 2 above). For our purposes, the more interesting results are that cash flows and cash holdings both reduce the likelihood that a firm will encounter difficulties in initiating or renewing lines during the crisis. Their interaction implies a substitution in the extent to which cash flow and cash holdings ease access to credit lines. However, the implied economic effect of the interaction term is relatively small.

\section{$\overline{\text { TABLE } 6 \text { ABOUT HERE }}$}

The results from Table 6 are new and interesting in their own right. Note that these findings cannot be replicated with standard archival data. LPC-Dealscan, for example, does not have information on loan requests that did not go through. In fact, no commercial database is likely to have data on companies' difficulties in renewing a line, much less on denials. It is also worth highlighting that CFOs would probably be reluctant to discuss publicly, tell financial analysts, or reveal in their 
firms' $10-\mathrm{Ks}$, their failure to obtain a credit line (they are inclined to do so here because our survey promises anonymity). In the extant literature, Sufi (2009) shows that profitable firms are more likely to have credit lines. Our results complement Sufi's by characterizing the difficulties firms face in renewing or initiating a line (beyond the outcome of having a line or its size) and by showing that the relation between profits and lines also holds in a crisis period.

\subsection{The Pricing of Credit Lines}

We find that companies draw less from their credit lines when internal liquidity is high. This points to a cost wedge between internal funds and credit lines. In this section, we examine the pricing of credit lines during the crisis and its relation with corporate liquidity.

In a follow-up survey conducted in the second quarter of 2009, we gather detailed data on credit line pricing structure for 2008 and 2009. We obtain information on basis point commitment fees that companies pay to retain the line, markup interest rates that banks charge above LIBOR/Prime on the used portion of the line, the credit line maturity (or "tenor"), and whether banks require collateral.

Table 7 relates various elements of credit line pricing to firm characteristics. Panel A reports basis point markups. The rightmost column shows that markups increased sharply during the crisis for all firms. Notably, these increases were much higher for non-regular borrowers. We find, for example, that the markup increased by about 71 basis points for private firms versus only 39 basis points for public companies. Panel B reports changes in the maturity of credit lines. The rightmost column shows a decline in the average line maturity during the crisis for all firm categories. The average maturity for large firms' lines, for example, fell by 6 months from 2008 to 2009, compared to a decline of 2 months for small firms. Note, however, that large firms' average line maturity in 2008 was 43 months, much longer than the 27 -month average maturity of small firms. We omit panels for commitment fees and collateral requirements to save space, but they lead to similar inferences about the tightening of credit conditions.

Overall, the terms associated with credit lines worsened from the perspective of borrowers over the crisis, especially for small, private, non-investment grade or unprofitable borrowers. Banks set significantly higher commitment fees and interest markups in 2009 (relative to 2008). They also reduced the maturities of the new lines and required more collateral coverage. These base results 
add to our understanding of the costs associated with credit lines in difficult times. Compared to the existing literature, they are unique in the level of detail provided and in characterizing the current crisis in particular. ${ }^{13}$

\section{TABLE 7 ABOUT HERE}

We use regression analysis to relate the pricing structure of credit lines to company characteristics, emphasizing the role of internal liquidity. Building on Shockley and Thakor's (1997) commitment fee model, in columns 1 and 2 of Table 8, we use a logit specification to regress an indicator that equals 1 if a firm pays a commitment fee on its lines (and 0 otherwise) on explanatory variables including firm size, ownership form, debt rating, reported access to credit, growth prospects, as well as controls for the size of the credit line, the line maturity, and the presence of collateral backing. We augment the Shockley and Thakor model by including cash flows, cash holdings, and an interaction term for these variables. We estimate similar models in columns 3 and 4, but employ OLS and use a continuous commitment fee dependent variable, focusing on the non-zero observations of the fee. In this way, the models in columns 3 and 4 capture the effect of firm liquidity on the "intensive margin" of the commitment fee structure. The models in columns 1 and 2 , in contrast, capture the "extensive margin" of the fee.

The logit regression in column 1 indicates that firms with high cash flows and high cash holdings are less likely to pay a commitment fee. The OLS regression in column 3 suggests that, conditional on paying a fee, the commitment fee declines with firms' cash flows and cash holdings. Economically, a one-IQR increase in cash flow (cash holdings) leads to a decline in the probability of paying a fee of about $5.3 \%(8.5 \%)$. On the intensive margin, the OLS results imply that a one-IQR increase in cash flow (cash holdings) reduces the commitment fee by 9 (12) basis points, which is a significant $18 \%$ (24\%) drop relative to the sample mean. The cash flow-cash holdings interaction term is positive and highly significant in the OLS fee model, indicating that there are diminishing marginal benefits to the independent effects of cash and cash flows on fee reductions. The evidence in Table 8 indicates that firms with more internal liquidity (cash flow and cash holdings) are likely to have easier access to credit lines and be charged lower prices for those facilities.

TABLE 8 ABOUT HERE 
These pricing results are new to the literature and shed additional light on the interplay between internal funds and credit lines. Combined with our previous analysis on line usage and availability during the crisis, our evidence seems consistent with Thakor's (1995) argument that firms acquire credit lines to handle credit rationing in bad times, but banks reserve the right to deny access or make it more costly to use those facilities.

\subsection{Covenant Violation and Credit Line Renegotiation}

We conduct a third survey in June, 2010 to explore the implications of covenant violations and line renegotiations during the financial crisis. The survey methodology is similar to that described in the Data Appendix and yields 396 observations. The results are presented in Table 9.

\section{TABLE 9 ABOUT HeRE}

It is important to consider not just covenant violation but also near violations in this analysis, since both may lead to similar responses. Panel A of Table 9 shows that during the 2008-2009 period, $18.6 \%$ of the sample firms with credit lines officially violated a covenant. Another $8.5 \%$ reported a near violation.

Panel B shows that all of the actual violations were related to financial covenants and $10.6 \%$ involved both financial and operational covenants. The panel also shows that for those that violated covenants, $9.1 \%$ of firms had all of their credit lines canceled. ${ }^{14}$ Another $1.4 \%$ had at least one line (but not all) canceled. About half of the firms (53.7\%) renegotiated their credit line. Interestingly, for more than one third of the firms, the violation did not lead to any renegotiation.

Panel C reports how covenant violation affected the renegotiation. Not surprisingly, most companies report an increase in the fees and markups associated with their credit lines after a violation. About half of firms that violate covenants report an increase of collateral requirements and a decline in the size of the credit facilities. Very few firms (about one-in-seven) report that the maturity of their lines was reduced. Interestingly, these changes are very similar for both violators and near-violators.

We also collect information on line drawdowns before and after violations (see rightmost columns of Panel A). Before the violation, both soon-to-be-violators and near-violators were drawing down about $58 \%$ of their lines. After the violation, drawdowns decrease sharply. Violators drew only $34.9 \%$ of their line and near-violators 35.1\%. We already know (from Panel C) that after renegotiation the 
size of the available facility was reduced for half of these firms. So the dollar drawdown impact is even stronger; i.e., smaller percentage drawdown from a smaller base.

What do these results imply? In our sample, credit lines appear to provide some relief during the worst part of the credit crisis. Approximately $81 \%$ of the firms experienced no violation or near violation. Of the $19 \%$ that did violate, more than one third experienced no change in the terms of their line. Hence, for about $88 \%$ of firms, credit lines appear to have offered access to liquidity during the crisis. For those that renegotiated, lines became more costly and restrictive. However, cancellation is rare. Only 7 firms or $2 \%$ of our full sample had all of their credit lines canceled during a severe credit crunch.

Our analysis implies that credit lines are not unconditional liquidity insurance because of the possibility that they can be revoked or made more costly to use (see Thakor (1995) and Sufi (2009)). To explore this further, we ask CFOs whether, after having lived through the recent credit crisis, they would be willing to pay for a "rainy day" credit facility — which could be a new facility or simply be greater access from their existing facility. By "rainy day" the idea is that the CFOs would have no intention of drawing on this facility except in dire circumstances. The results associated with this question are in Panel D of Table 9. More than $45 \%$ of respondents said that they would pay a small, moderate, or large premium $(30.4 \%, 13.6 \%$, and $1.3 \%$, respectively) to arrange a rainy day facility. About $55 \%$ said they would not be willing to pay for a rainy day credit line; nearly half of respondents (22\%) said they would not pay because they already held "excess cash for the same purpose."

\section{Liquidity and Real Corporate Policies During the Crisis}

There is notable interest in understanding connections between financial and real-side decisions. In particular, it is important to learn about how liquidity affects corporate spending when credit is tight. In this section, we study the real-side effects of liquidity coming from internal (cash holdings and cash flows) and external (credit lines) sources. We note that the connection between liquidity and spending during the crisis has not been stressed in the existing literature. Campello et al. (2010), for example, tabulate responses to a qualitative question in which managers indicate whether or not they use internal funds to finance investment. The authors, however, provide no quantitative assessment of the relation between liquidity and investment, and do not consider interactions (sub-

stitutability) between various sources of liquidity. Lins et al. (2010) consider the substitutability of 
cash and credit lines, but do not look at their impact on investment in a liquidity crisis. Ivashina and Scharfstein (2010) and Sufi (2009) are silent on the relation between liquidity and real-side policies. None of these papers examines the relation between line drawdowns and investment.

\subsection{Credit Lines and Spending}

We first regress real-side variables on cash holdings, lines of credit, and their interaction. We account for firm heterogeneity by including controls for firm size, ownership type, and credit ratings, among others. Following previous notation, the planned expenditures model can be written as:

$$
\text { PlannedExpenditure }_{i}=c+\alpha_{1} \text { CashHolding }_{i}+\alpha_{2} L C_{i}+\alpha_{3}(\text { CashHoldings } \times L C)_{i}+\gamma \mathbf{X}_{i}+\varepsilon_{i}
$$

where PlannedExpenditure is the firm's planned expenditures on, alternatively, fixed capital, technology, or employment; all expressed in expected percentage changes over the next 12 months. $L C$ is lines of credit over assets. $c, \mathbf{X}$, and $\varepsilon$ are defined similarly to Eq. (1).

We examine each real policy in Eq. (3) using OLS. We recognize, however, the potential for endogeneity in the above specification and thus also estimate our models using instrumental variables (IV). The IVs use lagged cash holdings, lagged lines of credit, their interaction, and the interaction of their projected values as instruments for the endogenous variables in the model. ${ }^{15}$

The results are reported in Table 10. We focus our discussion on investment, noting that inferences are generally similar for the other real-side variables. The estimates indicate that at the average level of cash holdings, an increase in lines of credit does not increase a firm's investment plans. Due to the positive coefficient on the interaction term, however, this internal-external liquidity dynamic changes at higher levels of cash holdings. Firms with more cash have their investment plans boosted by greater access to credit lines (see the upward sloping line in Panel A of Figure 2). Considering the IV estimation of column 2, for example, a one-IQR increase in credit lines $(=0.23)$ at the ninth decile of cash $(=0.25)$ leads the firm to increase investment by $2.8 \%$ over the next year. Given an average planned cut of $15 \%$, this implies a investment reduction of $12.2 \%$.

$$
\begin{aligned}
& \overline{\text { TABle } 10 \text { ABOUT HERE }} \\
& \overline{\text { Figure } 2 \text { ABOUt Here }}
\end{aligned}
$$


The estimates in Table 10 also imply a negative relation between investment and cash for firms without access to credit lines (see uninteracted term for CashHoldings). In the absence of a line, firms that plan to save the most also plan the largest investment cuts. However, as credit lines increase, this relation is reversed due to the positive interaction term: credit lines appear to free up internal funds for investment (see Panel B of Figure 2). For example, at the ninth decile of credit lines $(=0.50)$, a one-IQR increase in cash $(=0.10)$ would lead investment to increase by $3.2 \%$. By contrast, for a firm with no credit lines, investment would drop by $5.4 \%$.

The diagnostic statistics for our IV models are reported at the bottom of Table 10. The high $p$ values for Hansen's J-tests indicate that we never reject the joint null hypothesis that our instruments are uncorrelated with the error term in the real-side policy regressions and the model is well-specified. The low $p$-values associated with the first-stage $F$-test suggest that our instruments are relevant.

\subsection{Drawdowns and Spending}

Existing research suggests that firms proactively drew funds from their credit lines during the financial crisis (see Ivashina and Scharfstein (2010) and Campello et al. (2010)). However, it is unclear whether these funds are used to support corporate spending. Our data allow us to estimate the relation between investment, cash savings, and funds drawn from credit lines (drawdowns) in the crisis. Examining these relations is interesting in its own right. In addition, doing so also helps us strengthen the inferences we draw from the results in Table 10 on the relation between investment and credit lines. In particular, one could argue that the size of existing credit lines may proxy for investment opportunities during the crisis, and that the facilities themselves need not be used to fund investment spending. This potential endogeneity does not exist with respect to drawdowns.

We study the impact of drawdowns on planned investment, technology, and employment as in Eq. (3), replacing lines with drawdowns. One limitation we face is that we do not have lagged values on drawdowns, hence we can only estimate OLS models. The results are reported in Table 11.

\section{TABLE 11 ABOUT HERE}

The estimates in column 1 imply that a one-IQR increase in drawdowns $(=0.70)$ at the ninth decile of cash leads to an increase in planned investment of $14.8 \%$. While until now we relied on the total size of the credit line facility to gauge the impact of external funds on investment, we 
find markedly stronger, more statistically significant results when we look at the actual funds drawn from these facilities. Our findings are new to the literature and indicate that drawdown intensity provides finer information about how firms manage their lines and how liquidity management affects real decisions. One implication of our findings is that future research on lines of credit should focus more on drawdown activity.

\subsection{Growth Opportunities and the Internal-External Liquidity Interplay}

One could still be concerned that unobserved heterogeneity (perhaps exacerbated during the financial crisis) might influence our results. Differences in investment prospects during the crisis, for example, might simultaneously affect managers' investment plans and their choice between credit lines and cash. It is difficult to think of a story in which unmodeled investment prospects would explain the substitution effects that we obtain for internal-external liquidity; however, further exploring this possibility extends the analysis to its next logical step.

Recall, our results indicate that firms trade off saving cash and spending funds on capital investment. Presumably, it is costlier for firms to cancel their investment plans when investment has more positive prospects. Accordingly, the choice between saving and investing is likely to 'tilt' at different levels of access to credit lines, depending on the firm's investment prospects. For firms with a high opportunity cost of investment (more attractive investment prospects), it will be rational to switch from cash savings to investment spending starting at lower levels of credit lines. In the context of our econometric model (Eq. (3)), this would be equivalent to a stronger interaction effect between cash holdings and credit lines for firms with higher investment growth opportunities. ${ }^{16}$

This is what we observe in the data when we estimate investment regressions separately for subsamples of firms with high and low investment opportunities. The results are reported in Table 12, where we split the sample between firms that are in the bottom five deciles of the distribution of CFO self-reported long-term growth prospects ("low investment opportunity") and those that are in the top five deciles of the same distribution ("high investment opportunity"). Our IV estimates imply that the marginal effect of cash holdings on investment switches from negative to positive when credit lines are at around $25 \%$ of total assets for firms with high investment prospects (see Figure 3). For firms with low prospects, in contrast, the switch occurs only when credit lines exceed $62 \%$ of 
total assets (with the caveat that the estimates in this latter regression are statistically weak). The results in Table 12 indicate that the interplay between cash holdings and credit lines vary conditional on investment opportunities in economically sensible ways.

\section{TABLE 12 ABOUT HERE \\ Figure 3 ABOUt HERE}

The results of Section 3 reveal novel interaction effects between alternative sources of liquidity and corporate spending. At relatively low levels of internal liquidity (cash holdings), investment does not benefit from the firm's access to external liquidity (credit lines). Funds in the line facility might be used for other purposes. At higher levels of internal liquidity, however, access to external funds contributes to investment planning in a significant manner — this in a time when companies were drastically cutting spending. We note that theoretical work on connections between credit lines and investment is still scant. Our evidence, however, shows that credit lines played an important role in firms' investment policies during the crisis. In this way, it is consistent with Thakor's (1995) theoretical argument that firms use lines of credit for investment funding under tight credit conditions.

\section{Concluding Remarks}

In 2008-2009, companies worldwide were affected by a severe credit shock. We exploit this abrupt change in the availability of credit to shed light on the interaction between internal and external liquidity, and on the effects of liquidity on investment and other real decisions.

We analyze data from three surveys conducted in 2009 and 2010, each comprising approximately 400 firms private and public firms in the U.S. These data have features that, to our knowledge, have never been combined before, such as information on firms' spending plans (investment, technology, and employment), difficulty in accessing or renewing credit lines, the pricing of lines, covenant violations, line renegotiations, and drawdown activity.

From a financial management perspective, our tests indicate that the option to access liquidity from credit lines becomes less valuable when internal liquidity is abundant (even accounting for the fact that more profitable, liquid firms should find it easier to establish credit lines). Looking at real-side decisions, we find that firms appear to substitute cash savings for investment at low levels 
of credit lines. One can interpret these results as implying that, when unable to access credit lines, firms have to choose whether to save or invest. This internal-external liquidity dynamic changes, however, at higher levels of cash holdings. Firms with more cash have their investment plans boosted by greater access to credit lines. Our results are new in showing the importance of lines of credit for corporate spending decisions.

Our study uncovers important, new aspects of the liquidity role of credit lines when credit is tight. We find that the financial crisis limited, but in general did not preclude access to credit lines. According to our evidence, credit lines ease the impact of the financial crisis on capital investment and other real-side decisions, such as technology spending and employment. 


\section{Data Appendix}

\section{The Data Gathering Process}

To gather the data used in this study, we survey CFOs who are subscribers to CFO magazine and other executives who have been involved in previous surveys conducted by Duke University. For the main sample, we invited CFOs to take part in the survey via E-mail on February 16, 2009. A reminder E-mail was sent one week later. The survey closed on February 26, 2009.

We refer to the executives surveyed as "CFOs" since this is their prevailing job title. However, some of the executives have the title of Treasurer, Assistant Treasurer, V.P. Finance, or a related title. $C F O$ magazine sent out 10,500 E-mail invitations to U.S. firms. About $7 \%$ of these invitations did not reach the recipients (bounce backs). Additional invitations issued by Duke University helped offset the bounce backs from the $C F O$ magazine invitations. A supplementary survey, conducted in the second quarter of 2009, was used to gather data on the pricing of credit lines. A final survey, conducted in the second quarter of 2010 , gathered data on line violations and renegotiations ${ }^{17}$

We know annual sales and industry focus of the firms covered by the 10,500 E-mail invitations sent out by $C F O$ magazine (these numbers include bounce backs and invitations to financial institutions though financial firms are excluded from our analysis.) Our survey response rates range from about 3\% to almost $7 \%$ across different sales and industry categories.

\section{Comparison with Standard Datasets}

Table A.1 compares the U.S. survey sample with the COMPUSTAT universe. Since the bulk of research in corporate finance is based on COMPUSTAT, this comparison is important. Because COMPUSTAT reports information only on public firms, we restrict our attention to the set of public firms in our sample for the purpose of this comparison. Our survey sample includes 87 non-financial public company observations. We compare these firms to a sample of about 5,000 non-financial active firms from COMPUSTAT as of the end of the fiscal year 2008.

\section{TABLE A.1 ABOUT HERE}

Table A.1 shows that $47 \%$ of public survey firms have sales below $\$ 1$ billion. That figure is $68 \%$ for COMPUSTAT firms. We also find that $62 \%$ of survey firms are unrated or have a credit rating equal to or below BB+ compared to $52 \%$ for COMPUSTAT firms. The two samples are similar in terms of dividend payout policy and profitability. We find that $55 \%$ of survey firms did not pay dividends at the end of the fiscal year 2008 compared to $53 \%$ of COMPUSTAT firms. In addition, $16 \%$ of survey firms report negative profits compared to $23 \%$ in the COMPUSTAT universe. The two samples are very similar in terms of cash policy. Cash holdings average about $15 \%$ of total assets for our sample compared to $18 \%$ for COMPUSTAT firms. Finally, survey sample firms appear to have higher (similar) average (median) cash flows relative to those in COMPUSTAT.

An alternative dataset for studying credit lines is LPC-Dealscan. LPC-Dealscan doesn't have information on the drawdowns on the credit lines. However, it has useful information that we do not gather in our survey (such as the purpose of the credit line and the identity of the lenders). That database can be linked to other commercial databases such as CRSP and COMPUSTAT allowing for richer analysis, while ours cannot. In all, both survey and archival data have advantages and disadvantages in addressing questions regarding credit lines, as well as their impact on firm behavior. 


\section{References}

Acharya, V., H. Almeida, and M. Campello, 2010, "Aggregate Risk and the Choice Between Cash and Credit Lines," Working Paper, New York University and University of Illinois.

Almeida, H., M. Campello, and M. Weisbach, 2004, "The Cash Flow Sensitivity of Cash," Journal of Finance 59, 1777-1804.

Bolton, P., H. Chen and N. Wang, 2010, “A Unified Theory of Tobin's q, Corporate Investment, Financing, and Risk Management", working paper, Columbia University and MIT.

Boot, A., A. Thakor, and G. Udell, 1987, "Competition, Risk Neutrality And Loan Commitments," Journal of Banking and Finance 11, 449-471.

Campello, M., J. R. Graham, and C. R. Harvey, 2010, "The Real Effects of Financial Constraints: Evidence from a Financial Crisis," Journal of Financial Economics 97, 470-487.

Campello, M., E. Giambona, J. R. Graham, and C. R. Harvey, 2011, "Access to Liquidity and Corporate Investment in Europe During the Credit Crisis of 2009," working paper, University of Illinois, University of Amsterdam, and Duke University.

Chava, S., and A. Purnanandam, 2009, "The Effects of Banking Crisis on Bank-Dependent Borrowers," forthcoming, Journal of Financial Economics.

Holmstrom, B., and J. Tirole, 1998, "Private and Public Supply of Liquidity," Journal of Political Economy 106, 1-40.

Ivashina, V., and D. Scharfstein, 2010, "Bank Lending During the Financial Crisis of 2008," Journal of Financial Economics 97, 319-338.

Jimenez, G., J. Lopez, and J. Saurina, 2009, "Empirical Analysis of Corporate Credit Lines," Review of Financial Studies 22, 5069-5098.

Khawaja, A., and A. Mian, 2008, "Tracing the Impact of Bank Liquidity Shocks: Evidence from an Emerging Market," American Economic Review 98, 555-599. 
Kim, C., D. Mauer, and A. Sherman, 1998, "The Determinants of Corporate Liquidity: Theory and Evidence," Journal of Financial and Quantitative Analysis 33, 335-59.

Lins, K., H. Servaes, and P. Tufano, 2010, "What Drives Corporate Liquidity? An International Survey of Cash Holdings and Lines of Credit," forthcoming, Journal of Financial Economics.

Rogers, William, 1993, "Regression Standard Errors in Clustered Samples," Stata Technical Bulletin $13,19-23$.

Shockley , R. and A. Thakor, 1997, "Bank Loan Commitment Contracts: Data Theory and Tests," Journal of Money, Credit and Banking 29, 517- 534.

Sufi, A., 2009, "Bank Lines of Credit in Corporate Finance: An Empirical Analysis," Review of Financial Studies 22, 1057-1088.

Roberts, M., and A. Sufi, 2009, "Control Rights and Capital Structure: An Empirical Investigation," Journal of Finance 64, 1657-1695.

Thakor, A., 2005, "Do Loan Commitments Cause Overlending?" Journal of Money, Credit and Banking 37, 1067-1099.

Wooldridge, J., 2002, Econometric Analysis of Cross Section and Panel Data, Cambridge, MA: MIT Press. 


\section{Notes}

${ }^{1}$ To streamline the discussion, we only report results for the U.S. sample.

${ }^{2}$ Using data from Spain, Jimenez et al. (2009) find that firms near default draw down more funds from their lines.

${ }^{3}$ Contemporary work by Bolton et al. (2010) proposes a framework for theories relating liquidity management (including credit lines) and investment. Acharya et al. (2010) describes how firms' exposure to aggregate risk determines their choices between cash and credit lines.

${ }^{4}$ For ease of exposition, we often refer to the first quarter of 2008 as a "pre-crisis-peak" period. We don't mean to imply, however, that the financial crisis had not started by the time Lehman failed. Other researchers use similar ways to partition the crisis period around the time of the Lehman debacle. Ivashina and Scharfstein (2010), for example, denote the August 2007-July 2008 window as the "Crisis I" period, and the August 2008-December 2008 window as "Crisis II."

${ }^{5}$ Because respondents to the survey are anonymous, we are unable to directly link firms in our sample to commercially available databases. This is a disadvantage of our survey data, as we discuss in the Appendix.

${ }^{6}$ A similar liquidity "pecking order" is reported by Lins et al. (2010).

${ }^{7}$ A recent paper by Campello et al. (2010) sorts between different measures of financial constraints focusing on the crisis. Our study takes no stand on the measurement of financial constraints. The analysis in this section simply draws from other literatures on corporate borrowing to study how different firms are affected by the credit crisis.

${ }^{8}$ We also experimented with the use of industry-fixed effects and obtained similar results. Given the size of our sample, we exclude industry dummies in order to reduce the number of parameters to be estimated.

${ }^{9}$ In this section, we study changes between the first and ninth deciles of cash flow to be consistent with Sufi.

${ }^{10} \mathrm{We}$ do not find significant differences when we fit our new model separately for public and private firms. To save space, we present results for the entire sample and include a dummy variable for public status.

${ }^{11}$ Both estimates are statistically different from zero. Indeed, the "derivative" of lines of credit with respect to cash holdings is negative and reliably different from zero across the entire range of cash flow.

${ }^{12}$ We thank an anonymous referee for this suggestion. Amir Sufi's data is available from his personal website.

${ }^{13}$ Looking at the LTCM-Russia crisis, Chava and Purnanandam (2009) find that affected U.S. banks raised their loan spreads. However, the authors do not identify whether these loans refer to credit lines, nor do they look at the other components of credit facilities (such as maturity or collateral). Khawaja and Mian (2008) study the effect of the 1998 nuclear test crisis in Pakistan. These authors also do not differentiate between credit lines and other credit facilities, and look only at interest rates. They find no effect of the Pakistani liquidity crisis on loan pricing. Ivashina and Scharfstein (2010) look at data from 34 firms during the current crisis. They describe firms' abilities to draw funds from existing lines at low markups, but provide no evidence on the overall costs of those facilities, nor on how they changed during the crisis.

${ }^{14}$ To put this number into context, Roberts and Sufi (2009) find that $4 \%$ of a random sample of firms in breach of financial covenants in the 1995-2006 period terminate the relations with their creditors. The authors also report that net debt issuance becomes negative following a covenant violation.

${ }^{15}$ Details on this approach for modeling interactive-term instruments are found in Wooldridge (2002; Ch. 9).

${ }^{16}$ Put differently, while firms may be forced to choose between saving cash and investing in the 
absence of credit lines, the effect of cash on investment should switch from negative to positive at a relatively lower level of credit lines for firms with better investment opportunities (since sacrificing investments for the sake of saving funds is particularly costly for these firms).

${ }^{17}$ We do not discuss the details of these additional surveys here due to the strong similarities with the first survey. 


\section{Table 1 - Descriptive Statistics}

This table reports summary statistics for the key variables. The data are gathered from the 2009Q1 CFO survey. We include all firms with the exception of financial, governmental, and nonprofit organizations. Planned Investment, Planned Technology, and Planned Employment are CFO's expected percentage changes in these variables over the next 12 months. Cash Holdings is cash holdings and marketable securities as a percentage of total assets. Credit Line is bank credit lines as a percentage of total assets. Drawdown is the credit that is drawn as a percentage of total credit line. Difficulty Renewing Credit Line is a dummy variable taking the value of 1 if the firm experienced difficulty in initiating or renewing a credit line, and zero otherwise. Investment Growth Prospects is the CFO's rating of the firm's growth opportunities, ranging from 0 (no growth opportunities) to 100 (excellent growth opportunities). Access to Credit is the CFO's reported score of the firm ability to raise external funds during the crisis, ranging from zero (no access to external funds) to 100 (unlimited access to external funds). Cash Flow is return on assets (expressed as a percentage) in the year 2008. Large is a dummy variable taking a value of 1 if the firm's sales revenue is equal to or more than $\$ 1$ billion, and zero otherwise. Investment Grade is a dummy variable taking a value of 1 if the firm has a rating of BBB- or higher, and zero otherwise. Bank-Dependent is a dummy variable taking a value of 1 for a firm without a credit rating, and zero otherwise. Public is a dummy variable taking a value of 1 if the firm is publicly listed and zero otherwise.

\begin{tabular}{|c|c|c|c|c|c|c|}
\hline \multirow[t]{2}{*}{ Variables } & \multicolumn{6}{|c|}{ Descriptive Statistics } \\
\hline & Mean & Std. Dev. & $25^{\text {th }}$ Pct. & $50^{\text {th }}$ Pct. & $75^{\text {th }}$ Pct. & Obs. \\
\hline Planned Investment (\% change) & -14.73 & 43.11 & -30.00 & -10.00 & 0.00 & 345 \\
\hline Planned Tech Spending ( $\%$ change) & -5.76 & 30.97 & -10.00 & 0.00 & 0.00 & 311 \\
\hline Planned Employment (\% change) & -5.71 & 33.02 & -15.00 & -5.00 & 0.00 & 341 \\
\hline Cash Holdings in 2008 (\% of assets) & 12.22 & 15.74 & 2.00 & 5.50 & 16.00 & 334 \\
\hline Cash Holdings in 2009 (\% of assets) & 12.56 & 15.22 & 2.00 & 9.00 & 18.00 & 323 \\
\hline Credit Lines in 2008 (\% of assets) & 23.85 & 20.95 & 10.00 & 20.00 & 33.00 & 287 \\
\hline Credit Lines in 2009 (\% of assets) & 24.00 & 21.26 & 9.00 & 18.00 & 33.00 & 282 \\
\hline Drawdowns (\% of credit line) & 38.47 & 36.90 & 0.00 & 30.00 & 75.00 & 245 \\
\hline Difficulty Renewing Credit Line & 0.21 & 0.41 & 0.00 & 0.00 & 0.00 & 397 \\
\hline Investment Growth Prospects $(0-100)$ & 63.17 & 24.60 & 50.00 & 70.00 & 80.00 & 393 \\
\hline Access to Credit $(0-100)$ & 51.00 & 30.86 & 25.00 & 50.00 & 80.00 & 378 \\
\hline Cash Flow (\% of assets) & 8.98 & 17.06 & 3.00 & 8.00 & 15.00 & 338 \\
\hline Large & 0.22 & 0.42 & 0.00 & 0.00 & 0.00 & 397 \\
\hline Investment Grade & 0.18 & 0.39 & 0.00 & 0.00 & 0.00 & 397 \\
\hline Bank-Dependent & 0.72 & 0.45 & 0.00 & 1.00 & 1.00 & 397 \\
\hline Public & 0.22 & 0.41 & 0.00 & 0.00 & 0.00 & 397 \\
\hline
\end{tabular}




\section{Table 2 - Credit Lines and Cash Holdings by Firm Characteristics}

This table reports credit lines and cash holdings as a percentage of total assets, conditional on firm characteristics. The table also reports proportions of firms with credit lines, with difficulty in renewing credit lines conditional on facing credit difficulties in general, and drawdowns conditional on having access to a credit line as well as average drawdowns. The data are from the 2009Q1 CFO survey. Firms are defined as Small if their sales are less than $\$ 1$ billion, and Large otherwise. Private firms are those not listed on any stock exchange, while Public firms are listed on the NYSE, NASDAQ or AMEX. Non-Investment Grade firms are unrated or rated below BBB-. Investment Grade firms are those with a credit rating BBB- or higher. Bank-Dependent firms are those firms without a credit rating. Non-Bank-Dependent firms are those with a credit rating. Limited Access to Credit firms are those with a selfreported score of ability to raise external funds during the crisis in the bottom 3 deciles. Easy Access to Credit firms are those with a self-reported score in the top 3 deciles.

\begin{tabular}{|c|c|c|c|c|c|c|c|c|}
\hline & $\begin{array}{c}\text { Proportion of } \\
\text { Firms w/ Credit } \\
\text { Line }>0 \\
\text { (1) }\end{array}$ & $\begin{array}{l}\text { Proportion of Firms } \\
\text { w/ Difficulty in } \\
\text { Renewing Credit Line } \\
\text { (2) }\end{array}$ & $\begin{array}{l}\text { Proportion of Firms } \\
\text { w/ Drawdowns }>0 \\
\text { (3) }\end{array}$ & $\begin{array}{c}\text { Average } \\
\text { Drawdowns } \\
\text { (\% of Maximum) } \\
(4)\end{array}$ & $\begin{array}{l}\text { Credit Line/Assets } \\
\text { in 2009Q1 } \\
\text { (5) }\end{array}$ & $\begin{array}{l}\text { Credit Line/Assets } \\
\text { in 2008Q1 } \\
\text { (6) }\end{array}$ & $\begin{array}{c}\text { Cash/Assets } \\
\text { in 2009Q1 } \\
(7)\end{array}$ & $\begin{array}{c}\text { Cash/Assets } \\
\text { in 2008Q1 } \\
\text { (8) }\end{array}$ \\
\hline Small & 0.75 & 0.21 & 0.69 & 42.63 & 24.65 & 25.12 & 12.99 & 13.26 \\
\hline Large & 0.92 & 0.22 & 0.58 & 27.26 & 21.45 & 20.31 & 9.40 & 9.82 \\
\hline Diff. Small - Large & $-0.17^{* * *}$ & -0.01 & 0.11 & $15.38^{* * *}$ & 3.21 & 4.82 & 3.59 & 3.44 \\
\hline Private & 0.80 & 0.23 & 0.69 & 41.72 & 25.84 & 25.77 & 11.66 & 11.77 \\
\hline Public & 0.73 & 0.14 & 0.57 & 25.59 & 15.91 & 16.65 & 14.73 & 15.82 \\
\hline Diff. Private - Public & 0.07 & $0.09^{*}$ & 0.12 & $16.13^{* * *}$ & $9.93^{* * *}$ & $9.12^{* * *}$ & -3.08 & $-4.05^{* * *}$ \\
\hline Non-Investment Grade & 0.78 & 0.23 & 0.68 & 42.44 & 25.28 & 25.35 & 12.02 & 12.16 \\
\hline Investment Grade & 0.82 & 0.14 & 0.57 & 20.79 & 18.09 & 18.26 & 13.34 & 14.39 \\
\hline Diff. Non-Inv. - Inv. Grade & -0.04 & 0.09 & 0.11 & $21.66^{* * *}$ & $7.19^{* *}$ & $7.09^{* *}$ & -1.32 & -2.23 \\
\hline Bank-Dependent & 0.75 & 0.21 & 0.69 & 41.57 & 25.91 & 26.42 & 12.78 & 12.74 \\
\hline Non-Bank-Dependent & 0.88 & 0.21 & 0.61 & 31.30 & 19.12 & 18.56 & 10.70 & 12.07 \\
\hline Diff. Bank - Non-Bank & $-0.13^{* * *}$ & -0.00 & 0.08 & $10.27^{*}$ & $6.79^{* *}$ & $7.86^{* * *}$ & 2.07 & 0.67 \\
\hline Limited Access to Credit & 0.68 & 0.41 & 0.78 & 53.86 & 29.12 & 31.33 & 9.25 & 12.02 \\
\hline Easy Access to Credit & 0.83 & 0.03 & 0.53 & 25.44 & 20.40 & 19.76 & 14.38 & 13.33 \\
\hline Diff. Limited - Easy & $-0.16^{* * *}$ & $0.38^{* * *}$ & $0.26^{* * *}$ & $28.41^{* * *}$ & $8.72^{* *}$ & $11.57^{* * *}$ & $-5.13^{* *}$ & -1.31 \\
\hline Unprofitable & 0.63 & 0.42 & 0.83 & 63.60 & 29.25 & 30.40 & 8.98 & 12.37 \\
\hline Profitable & 0.83 & 0.16 & 0.61 & 33.55 & 23.24 & 23.13 & 13.02 & 12.54 \\
\hline Diff. Unprofit. - Profit. & $-0.21^{* * *}$ & $0.27^{* * *}$ & $0.22^{* *}$ & $30.05^{* * *}$ & $6.01^{*}$ & $7.28^{* *}$ & $-4.03^{*}$ & -0.18 \\
\hline
\end{tabular}


Table 3 - Correlations between Credit Lines, Cash Holdings, and Drawdowns in 2008 and 2009

This table reports correlation coefficients between credit lines, cash holdings, and drawdowns in 2008Q1 and 2009Q1 during the crisis. Refer to Table 1 for detailed variable definitions. The data are gathered from the 2009Q1 survey.

\begin{tabular}{|c|c|c|c|c|c|}
\hline & $\begin{array}{l}\text { Credit Line } \\
\text { in 2009Q1 }\end{array}$ & $\begin{array}{c}\text { Credit Line } \\
\text { in 2008Q1 } \\
\end{array}$ & $\begin{array}{c}\text { Cash } \\
\text { in 2009Q1 } \\
\end{array}$ & $\begin{array}{c}\text { Cash } \\
\text { in 2008Q1 } \\
\end{array}$ & $\begin{array}{c}\text { Drawdowns } \\
\text { in 2009Q1 }\end{array}$ \\
\hline Credit Line in 2009Q1 & 1.000 & & & & \\
\hline Credit Line in 2008Q1 & $0.926^{* * *}$ & 1.000 & & & \\
\hline Cash Holdings in 2009Q1 & $-0.106^{*}$ & -0.090 & 1.000 & & \\
\hline Cash Holdings in 2008Q1 & -0.042 & -0.022 & $0.863^{* * *}$ & 1.000 & \\
\hline Drawdowns in 2009Q1 & $0.241^{* * *}$ & $0.249^{* * *}$ & $-0.332^{* * *}$ & $-0.239 * * *$ & 1.000 \\
\hline
\end{tabular}

Note: ${ }^{* * *},{ }^{* *}$, and $*$ indicate statistical significance at the $1 \%, 5 \%$, and $10 \%$ (two-tail) test levels, respectively. 


\section{Table 4 - Drawdowns versus External Financing in the Crisis}

This table reports mean comparisons of the ratio of drawdowns to the sum of total external funds (drawdowns, equity issuances, short-term debt issuances, long-term debt issuances, and commercial paper issuances). The data are gathered from the 2009Q1 survey.

\begin{tabular}{|c|c|c|c|}
\hline Characteristics & & & Difference \\
\hline Size & $\begin{array}{l}\text { Large } \\
\text { Small }\end{array}$ & $\begin{array}{l}0.097 \\
0.244\end{array}$ & $-0.147^{*}$ \\
\hline Ownership & $\begin{array}{l}\text { Public } \\
\text { Private }\end{array}$ & $\begin{array}{l}0.035 \\
0.253\end{array}$ & $-0.218^{* *}$ \\
\hline Ratings & $\begin{array}{l}\text { Investment Grade } \\
\text { Non-Investment Grade }\end{array}$ & $\begin{array}{l}0.071 \\
0.237\end{array}$ & $-0.166^{*}$ \\
\hline Dependence on Bank Credit & $\begin{array}{l}\text { Non-Bank Dependent } \\
\text { Bank-Dependent }\end{array}$ & $\begin{array}{l}0.151 \\
0.227\end{array}$ & -0.076 \\
\hline Access to External Credit & $\begin{array}{l}\text { Easy Access to Credit } \\
\text { Limited Access to Credit }\end{array}$ & $\begin{array}{l}0.070 \\
0.305\end{array}$ & $-0.234^{* * *}$ \\
\hline Profitability & $\begin{array}{l}\text { Profitable } \\
\text { Unprofitable }\end{array}$ & $\begin{array}{l}0.180 \\
0.512\end{array}$ & $-0.333^{* *}$ \\
\hline
\end{tabular}

$\overline{\text { Note: }}{ }^{* *},{ }^{* *}$, and $*$ indicate statistical significance at the $1 \%, 5 \%$, and $10 \%$ (two-tail) test levels, respectively. 
Table 5 - The Relation between Cash Holdings, Cash Flows, Credit Lines, and Drawdowns: Regression Analysis

This table reports OLS results from credit line regressions. Columns 1 and 2 of Panel A use as dependent variable the ratio between the amount of credit lines available to the sum of credit lines plus cash holdings. The dependent variable is the amount of credit lines available as a percentage of total assets in columns 3 to 6 . In Panel B, the dependent variable is the ratio between the amount of unused credit lines available to the sum of credit lines plus cash flow in Columns 1 and 2. The dependent variable is the percentage drawn down from available credit lines in columns 3 to 6 . All regressions include a constant term (not reported). The data are gathered from the 2009Q1 survey. Results in column 6 are based on Sufi's (2009) sample. Refer to Table 1 for detailed independent variable definitions. Easy Access to Credit is a dummy variable taking a value of 1 if the CFO's reported score of the firm ability to raise external funds during the crisis in the bottom 3 deciles, and zero otherwise. t-statistics reported in parentheses are based on heteroskedasticityconsistent standard errors adjusted for clustering across observations of a given industry.

\begin{tabular}{|c|c|c|c|c|c|c|}
\hline \multirow[t]{2}{*}{ Panel A: Size of Credit Line } & \multicolumn{2}{|c|}{$\begin{array}{c}\text { Dep. Var.: Credit Line / (Credit Line + Cash) } \\
\text { (Survey Sample) }\end{array}$} & \multicolumn{4}{|c|}{$\begin{array}{l}\text { Dep. Var.: Credit Line / Assets } \\
\text { (Survey Sample) } \\
\text { (Sufi's Sample) }\end{array}$} \\
\hline & $\begin{array}{c}\text { Public Firms } \\
(1)\end{array}$ & $\begin{array}{l}\text { Private Firms } \\
(2) \\
\end{array}$ & (3) & (4) & $(5)$ & $(6)$ \\
\hline Cash Flow & $\begin{array}{l}0.471^{* * *} \\
(2.64)\end{array}$ & $\begin{array}{l}0.060 \\
(0.31)\end{array}$ & $\begin{array}{c}0.226^{* *} \\
(1.97)\end{array}$ & $\begin{array}{c}0.240^{*} \\
(1.92)\end{array}$ & $\begin{array}{c}0.325^{* *} \\
(2.20)\end{array}$ & $\begin{array}{c}0.371^{* * * *} \\
(6.37)\end{array}$ \\
\hline Cash Holdings & & & & $\begin{array}{c}-0.192^{* *} \\
(-2.33)\end{array}$ & $\begin{array}{c}-0.161^{* *} \\
(-2.43)\end{array}$ & $\begin{array}{c}-0.288^{* * *} \\
(-10.53)\end{array}$ \\
\hline Cash Flow $\times$ Cash Holdings & & & & & $\begin{array}{c}-0.424^{* *} \\
(-2.33)\end{array}$ & $\begin{array}{c}-0.761^{* * *} \\
(-6.88)\end{array}$ \\
\hline Large & $\begin{array}{l}0.108 \\
(1.20)\end{array}$ & $\begin{array}{c}0.191^{* *} \\
(2.37)\end{array}$ & $\begin{array}{c}0.080^{* *} \\
(2.47)\end{array}$ & $\begin{array}{c}0.076^{* *} \\
(2.45)\end{array}$ & $\begin{array}{c}0.075^{* *} \\
(2.45)\end{array}$ & $\begin{array}{c}-0.044^{* * *} \\
(2.64)\end{array}$ \\
\hline Public Firm & & & $\begin{array}{c}-0.089^{* *} \\
(-2.50)\end{array}$ & $\begin{array}{l}-0.056^{*} \\
(-1.85)\end{array}$ & $\begin{array}{c}-0.061^{* *} \\
(-2.04)\end{array}$ & \\
\hline Investment Grade & $\begin{array}{l}0.026 \\
(0.25)\end{array}$ & $\begin{array}{c}-0.195^{* *} \\
(-2.31)\end{array}$ & $\begin{array}{l}-0.053 \\
(-1.09)\end{array}$ & $\begin{array}{c}-0.079^{* *} \\
(-2.12)\end{array}$ & $\begin{array}{c}-0.077^{* *} \\
(-2.10)\end{array}$ & $\begin{array}{l}-0.017 \\
(-0.89)\end{array}$ \\
\hline Easy Access to Credit & $\begin{array}{l}0.093 \\
(1.34)\end{array}$ & $\begin{array}{c}-0.013^{* * *} \\
(-2.58)\end{array}$ & $\begin{array}{l}-0.022 \\
(-1.46)\end{array}$ & $\begin{array}{l}-0.015 \\
(-0.80)\end{array}$ & $\begin{array}{l}-0.016 \\
(-0.84)\end{array}$ & \\
\hline Investment Growth Prospects & $\begin{array}{l}-0.210 \\
(-0.77)\end{array}$ & $\begin{array}{c}-0.121^{* *} \\
(-2.11)\end{array}$ & $\begin{array}{l}-0.035 \\
(-1.04)\end{array}$ & $\begin{array}{l}-0.014 \\
(-0.40)\end{array}$ & $\begin{array}{l}-0.024 \\
(-0.63)\end{array}$ & $\begin{array}{c}-0.007^{* *} \\
(-2.50)\end{array}$ \\
\hline Obs. & 54 & 226 & 309 & 282 & 282 & 1,908 \\
\hline Adj.- $R^{2}$ & 0.092 & 0.056 & 0.087 & 0.112 & 0.120 & 0.270 \\
\hline \multirow[t]{3}{*}{ Panel B: Drawdowns } & \multirow{2}{*}{\multicolumn{2}{|c|}{$\begin{array}{c}\text { Dep. Var.: Unused LC / (Unused LC + Cash) } \\
\text { (Survey Sample) }\end{array}$}} & \multicolumn{4}{|c|}{ Dep. Var.: Drawdowns / LC } \\
\hline & & & & Irvey Samp & & (Sufi's Sample) \\
\hline & $\begin{array}{l}\text { Public Firms } \\
\text { (1) }\end{array}$ & $\begin{array}{c}\text { Private Firms } \\
(2) \\
\end{array}$ & (3) & (4) & (5) & (6) \\
\hline Cash Flow & $\begin{array}{l}0.129^{* * *} \\
(5.29)\end{array}$ & $\begin{array}{l}0.096 \\
(0.93)\end{array}$ & $\begin{array}{c}-0.643^{* * *} \\
(-4.35)\end{array}$ & $\begin{array}{c}-0.496 * * * \\
(-3.51)\end{array}$ & $\begin{array}{c}-0.571^{* * *} \\
(-2.57)\end{array}$ & $\begin{array}{l}-0.589^{* * *} \\
(-4.39)\end{array}$ \\
\hline Cash Holdings & & & & $\begin{array}{c}-0.763 * * * \\
(-5.28)\end{array}$ & $\begin{array}{c}-0.847^{* * *} \\
(-3.77)\end{array}$ & $\begin{array}{c}-0.746^{* * *} \\
(-9.61)\end{array}$ \\
\hline Cash Flow $\times$ Cash Holdings & & & & & $\begin{array}{l}0.644 \\
(0.65)\end{array}$ & $\begin{array}{l}0.124 \\
(0.42)\end{array}$ \\
\hline Large & $\begin{array}{l}-0.009 \\
(-0.58)\end{array}$ & $\begin{array}{l}0.042 \\
(0.75)\end{array}$ & $\begin{array}{c}-0.117^{* *} \\
(-2.41)\end{array}$ & $\begin{array}{l}-0.112^{* * *} \\
(-2.72)\end{array}$ & $\begin{array}{c}-0.110^{* * *} \\
(-2.67)\end{array}$ & $\begin{array}{c}-0.098^{* * *} \\
(-3.45)\end{array}$ \\
\hline Public Firm & & & $\begin{array}{l}-0.047 \\
(-0.95)\end{array}$ & $\begin{array}{l}-0.048 \\
(-1.18)\end{array}$ & $\begin{array}{l}-0.045 \\
(-1.08)\end{array}$ & \\
\hline Investment Grade & $\begin{array}{l}0.031 \\
(0.96)\end{array}$ & $\begin{array}{l}0.002 \\
(0.05)\end{array}$ & $\begin{array}{c}-0.093^{* * *} \\
(-3.37)\end{array}$ & $\begin{array}{l}-0.069 \\
(-1.15)\end{array}$ & $\begin{array}{l}-0.070 \\
(-1.14)\end{array}$ & $\begin{array}{c}-0.110^{* * * *} \\
(-3.18)\end{array}$ \\
\hline Easy Access to Credit & $\begin{array}{l}-0.003 \\
(-0.11)\end{array}$ & $\begin{array}{l}0.022 \\
(0.81)\end{array}$ & $\begin{array}{c}-0.068^{* *} \\
(-2.31)\end{array}$ & $\begin{array}{c}-0.086^{* *} \\
(-2.29)\end{array}$ & $\begin{array}{c}-0.085^{* *} \\
(-2.26)\end{array}$ & \\
\hline Investment Growth Prospects & $\begin{array}{l}-0.045 \\
(-0.88)\end{array}$ & $\begin{array}{l}0.097 \\
(1.38)\end{array}$ & $\begin{array}{l}-0.098 \\
(-0.51)\end{array}$ & $\begin{array}{l}-0.140 \\
(-0.66)\end{array}$ & $\begin{array}{l}-0.139 \\
(-0.66)\end{array}$ & $\begin{array}{c}0.0104 \\
(1.02)\end{array}$ \\
\hline Obs. & 37 & 149 & 208 & 189 & 189 & 1,428 \\
\hline Adj.- $R^{2}$ & 0.055 & 0.023 & 0.161 & 0.249 & 0.250 & 0.190 \\
\hline
\end{tabular}

Note: ${ }^{* * *},{ }^{* *}$, and ${ }^{*}$ indicate statistical significance at the $1 \%, 5 \%$, and $10 \%$ (two-tail) test levels, respectively. 


\section{Table 6 - Difficulty in Initiating/Renewing a Credit Line: Probit Regressions}

This table reports results from a probit regression where the dependent variable takes the value of 1 for firms that experienced difficulty in initiating/renewing a credit line during the crisis and zero otherwise. All regressions include a constant term (not reported). The data are gathered from the 2009Q1 survey. Refer to Table 1 for detailed independent variable definitions. $t$-statistics reported in parentheses are based on heteroskedasticity-consistent standard errors adjusted for clustering across observations of a given industry.

\begin{tabular}{|c|c|c|c|}
\hline & $(1)$ & $(2)$ & $(3)$ \\
\hline Cash Flow & $\begin{array}{c}-0.009^{*} \\
(-1.79)\end{array}$ & $\begin{array}{l}-0.007 \\
(-1.17)\end{array}$ & $\begin{array}{c}-0.018^{* *} \\
(-2.32)\end{array}$ \\
\hline Cash Holdings & & $\begin{array}{c}-0.014^{*} \\
(-1.69)\end{array}$ & $\begin{array}{c}-0.025^{* *} \\
(-2.14)\end{array}$ \\
\hline Cash Flow $\times$ Cash Holdings & & & $\begin{array}{c}0.001^{* *} \\
(2.19)\end{array}$ \\
\hline Large & $\begin{array}{l}0.165 \\
(0.61)\end{array}$ & $\begin{array}{l}-0.021 \\
(-0.08)\end{array}$ & $\begin{array}{l}0.021 \\
(0.07)\end{array}$ \\
\hline Public Firm & $\begin{array}{c}-0.668^{*} \\
(-1.71)\end{array}$ & $\begin{array}{l}-0.334 \\
(-0.89)\end{array}$ & $\begin{array}{l}-0.360 \\
(-0.94)\end{array}$ \\
\hline Investment Grade & $\begin{array}{l}-0.101 \\
(-0.36)\end{array}$ & $\begin{array}{l}-0.046 \\
(-0.19)\end{array}$ & $\begin{array}{l}-0.008 \\
(-0.04)\end{array}$ \\
\hline Easy Access to Credit & $\begin{array}{c}-0.800 * * * \\
(-8.22)\end{array}$ & $\begin{array}{c}-1.030^{* * *} \\
(-9.46)\end{array}$ & $\begin{array}{c}-1.056^{* * *} \\
(-8.85)\end{array}$ \\
\hline Invest. Growth Prospects & $\begin{array}{c}-0.007^{* *} \\
(-2.04)\end{array}$ & $\begin{array}{c}-0.009^{* *} \\
(-2.32)\end{array}$ & $\begin{array}{c}-0.008^{* *} \\
(-2.04)\end{array}$ \\
\hline Obs. & 318 & 286 & 286 \\
\hline Pseudo-R ${ }^{2}$ & 0.116 & 0.154 & 0.168 \\
\hline
\end{tabular}

Note: ${ }^{* *},{ }^{* *}$, and $*$ indicate statistical significance at the $1 \%, 5 \%$, and $10 \%$ (two-tail) test levels, respectively. 


\section{Table 7 - Credit Lines Markup and Maturity by Firm Characteristics}

This table reports variable rate markup on LIBOR and prime rates and maturity of credit lines by firm characteristics in 2008 and 2009 . The data are gathered from the 2009Q2 survey. Firms are defined as Small if their sales are less than $\$ 1$ billion, and Large otherwise. Private firms are those not listed in any stock exchange, while Public firms are listed on the NYSE, NASDAQ or AMEX. NonInvestment Grade firms are unrated or rated below BBB-. Investment Grade firms are those with a credit rating BBB- or higher. BankDependent firms do not have a credit rating. Non-Bank-Dependent firms are those with a credit rating. Limited Access to Credit firms are those with a CFO's reported score of the firm ability to raise external funds during the crisis in the sample bottom 3 deciles. Easy Access to Credit firms are those where the CFO has reported a score in the sample top 3 deciles.

\begin{tabular}{|c|c|c|c|}
\hline Panel A: Basis Point Markup on LIBOR/Prime Rate & In 2009 & In 2008 & $\begin{array}{c}\text { Difference } \\
2009-2008\end{array}$ \\
\hline Small & 196.790 & 127.511 & $69.278^{* * *}$ \\
\hline Large & 152.300 & 109.272 & $43.028^{* *}$ \\
\hline Diff. Small - Large & 44.490 & 18.239 & \\
\hline Private & 195.229 & 124.340 & $70.889^{* * *}$ \\
\hline Public & 161.963 & 123.360 & $38.603^{* *}$ \\
\hline Diff. Private - Public & 33.266 & 0.980 & \\
\hline Non-Investment Grade & 189.299 & 119.179 & $70.120^{* * *}$ \\
\hline Investment Grade & 184.074 & 155.037 & 29.037 \\
\hline Diff. Non-Inv. - Inv. Grade & 5.225 & -35.858 & \\
\hline Bank-Dependent & 171.895 & 114.260 & $57.635^{* * *}$ \\
\hline Non-Bank-Dependent & 234.448 & 151.323 & $83.125^{* *}$ \\
\hline Diff. Bank - Non-Bank & -62.553 & -37.063 & \\
\hline Limited Access to Credit & 355.861 & 191.366 & $164.494^{* * *}$ \\
\hline Easy Access to Credit & 141.252 & 105.127 & $36.125^{* * *}$ \\
\hline Diff. Limited - Easy & $214.609^{* * *}$ & $86.239^{* * *}$ & \\
\hline Unprofitable & 213.145 & 117.936 & $95.210^{* * *}$ \\
\hline Profitable & 190.983 & 128.424 & $62.559^{* * *}$ \\
\hline Diff. Unprofit. - Profit. & 22.162 & -10.488 & \\
\hline Panel B: LC Maturity (in months) & In 2009 & In 2008 & $\begin{array}{c}\text { Difference } \\
2009-2008\end{array}$ \\
\hline Small & 25.093 & 26.780 & -1.687 \\
\hline Large & 37.289 & 43.368 & $-6.079^{* * *}$ \\
\hline Diff. Small - Large & $-12.196^{* * *}$ & $-16.588^{* * *}$ & \\
\hline Private & 24.967 & 26.424 & -1.457 \\
\hline Public & 38.135 & 45.270 & $-7.135^{* * *}$ \\
\hline Diff. Private - Public & $-13.168^{* * *}$ & $-18.846^{* * *}$ & \\
\hline Non-Investment Grade & 25.857 & 29.050 & $-3.193^{* * *}$ \\
\hline Investment Grade & 37.704 & 36.593 & 1.111 \\
\hline Diff. Non-Inv. - Inv. Grade & $-11.847^{* * *}$ & $-7.543^{*}$ & \\
\hline Bank-Dependent & 25.057 & 27.447 & $-2.390^{* *}$ \\
\hline Non-Bank-Dependent & 35.064 & 38.191 & -3.128 \\
\hline Diff. Bank - Non-Bank & $-10.007^{* * *}$ & $-10.744^{* * *}$ & \\
\hline Limited Access to Credit & 22.488 & 28.326 & $-5.837^{* * *}$ \\
\hline Easy Access to Credit & 29.062 & 30.669 & -1.607 \\
\hline Diff. Limited - Easy & $-6.574^{*}$ & -2.343 & \\
\hline Unprofitable & 20.536 & 23.000 & -2.464 \\
\hline Profitable & 28.822 & 31.212 & $-2.390^{* *}$ \\
\hline Diff. Unprofit. - Profit. & $-8.286^{*}$ & $-8.212^{* *}$ & \\
\hline
\end{tabular}

Note: ${ }^{* *},{ }^{* *}$, and ${ }^{*}$ indicate statistical significance at the $1 \%, 5 \%$, and $10 \%$ (two-tail) test levels, respectively. 


\section{Table 8 - Credit Lines Commitment Fees and Firm Characteristics}

This table reports logit and OLS results from commitment fee regression models. In the logit regressions, the dependent variable is equal to 1 if the firm reports a commitment fee for its outstanding credit line and zero otherwise. In the OLS regressions, the dependent variable is the commitment fee in basis points. All regressions include a constant term (not reported). The data are gathered from the 2009Q2 survey. Refer to Table 1 for detailed independent variable definitions. t-statistics reported in parentheses are based on heteroskedasticity-consistent standard errors adjusted for clustering across observations of a given industry.

\begin{tabular}{|c|c|c|c|c|}
\hline & \multicolumn{2}{|c|}{ Logit } & \multicolumn{2}{|c|}{ OLS } \\
\hline & $(1)$ & $(2)$ & $(3)$ & $(4)$ \\
\hline Cash Flow & $\begin{array}{c}-0.022^{*} \\
(-1.66)\end{array}$ & $\begin{array}{l}-0.015 \\
(-0.69)\end{array}$ & $\begin{array}{c}-0.010^{* *} \\
(-2.05)\end{array}$ & $\begin{array}{c}-0.020^{* * *} \\
(-4.98)\end{array}$ \\
\hline Cash Holdings & $\begin{array}{c}-0.025^{* *} \\
(-2.51)\end{array}$ & $\begin{array}{c}-0.022^{*} \\
(-1.68)\end{array}$ & $\begin{array}{c}-0.014^{* *} \\
(-2.27)\end{array}$ & $\begin{array}{c}-0.015^{* * *} \\
(-3.07)\end{array}$ \\
\hline Cash Flow $\times$ Cash Holdings & & $\begin{array}{c}0.000 \\
(-0.44)\end{array}$ & & $\begin{array}{c}0.058^{* * *} \\
(6.08)\end{array}$ \\
\hline Large & $\begin{array}{c}1.272^{* * *} \\
(3.17)\end{array}$ & $\begin{array}{c}1.261^{* * *} \\
(3.06)\end{array}$ & $\begin{array}{c}-0.002^{*} \\
(-1.95)\end{array}$ & $\begin{array}{c}-0.003^{* *} \\
(-2.50)\end{array}$ \\
\hline Public Firm & $\begin{array}{c}-0.985^{* *} \\
(-2.08)\end{array}$ & $\begin{array}{c}-0.967^{* *} \\
(-2.01)\end{array}$ & $\begin{array}{l}-0.002 \\
(-1.07)\end{array}$ & $\begin{array}{l}-0.003 \\
(-1.11)\end{array}$ \\
\hline Investment Grade & $\begin{array}{l}0.071 \\
(0.09)\end{array}$ & $\begin{array}{l}0.080 \\
(0.10)\end{array}$ & $\begin{array}{c}0.005^{* * *} \\
(3.63)\end{array}$ & $\begin{array}{c}0.005^{* * *} \\
(3.11)\end{array}$ \\
\hline Easy Access to Credit & $\begin{array}{l}-0.236 \\
(-1.20)\end{array}$ & $\begin{array}{l}-0.221 \\
(-1.01)\end{array}$ & $\begin{array}{c}-0.010^{* * *} \\
(-5.97)\end{array}$ & $\begin{array}{c}-0.010^{* * *} \\
(-6.29)\end{array}$ \\
\hline Size of Credit Line & $\begin{array}{l}-0.008 \\
(-0.94)\end{array}$ & $\begin{array}{l}-0.009 \\
(-0.94)\end{array}$ & $\begin{array}{l}0.002 \\
(1.18)\end{array}$ & $\begin{array}{l}0.002 \\
(1.27)\end{array}$ \\
\hline Investment Growth Prospects & $\begin{array}{l}-0.006 \\
(-0.94)\end{array}$ & $\begin{array}{l}-0.007 \\
(-1.08)\end{array}$ & $\begin{array}{c}-0.010^{* * *} \\
(-5.82)\end{array}$ & $\begin{array}{c}-0.009^{* * *} \\
(-6.64)\end{array}$ \\
\hline Credit Line Collateral Dummy & $\begin{array}{l}0.438^{*} \\
(1.75)\end{array}$ & $\begin{array}{l}0.429^{*} \\
(1.70)\end{array}$ & $\begin{array}{c}0.002 \\
(-0.12)\end{array}$ & $\begin{array}{c}0.003 \\
(-0.25)\end{array}$ \\
\hline Credit Line Maturity (in Months) & $\begin{array}{c}0.045^{\text {**** }} \\
(3.61)\end{array}$ & $\begin{array}{c}0.044^{* * *} \\
(3.42)\end{array}$ & $\begin{array}{c}0.000^{* *} \\
(-2.25)\end{array}$ & $\begin{array}{l}0.000^{*} \\
(-1.87)\end{array}$ \\
\hline Obs. & 160 & 160 & 92 & 90 \\
\hline Pseudo- $\mathrm{R}^{2}$ & 0.156 & 0.157 & 0.369 & 0.393 \\
\hline
\end{tabular}

Note: ${ }^{* * *},{ }^{* *}$, and ${ }^{*}$ indicate statistical significance at the $1 \%, 5 \%$, and $10 \%$ (two-tail) test levels, respectively. 


\section{Table 9 - Covenant Violation, Renegotiation, and Role of Credit Lines During the Credit Crisis}

This table reports covenant violations and changes in the terms of credit lines in the 2008-2009 period. The data are gathered from the 2010Q2 survey. Panel A shows the percentage of credit lines that violated covenants and drawdowns as a percentage of available credit line before and after covenant violations. Panel B shows, for the subsample of firms that violated covenants, the percentage of firms that violated financial and/or operational covenants and whether, as a consequence of the violation, the credit line had to be canceled or renegotiated. Panel $\mathrm{C}$ shows the changes in the terms of credit lines after a violation. Panel D shows what percentage of firms are more willing to pay now (as a consequence of the credit crisis) a commitment fee to have access to a credit line accessible in case of necessity.

Panel A: Covenant Violation and Drawdowns

\begin{tabular}{|c|c|c|c|c|c|c|}
\hline \multirow[b]{3}{*}{ No Violation } & \multicolumn{6}{|c|}{ Drawdown Activity Around Violation } \\
\hline & Obs. & $\%$ & $\begin{array}{c}\text { Before } \\
\text { (\% of Credit Line) }\end{array}$ & $\begin{array}{c}\text { After } \\
\text { (\% of Credit Line) }\end{array}$ & & \\
\hline & 258 & 72.88 & & & & \\
\hline Near Violation & 30 & 8.47 & 57.78 & 35.08 & & \\
\hline Violation & 66 & 18.64 & 58.51 & 34.85 & & \\
\hline \multicolumn{7}{|c|}{ Panel B: Reason for Violation and Consequences } \\
\hline \multirow[t]{3}{*}{$\begin{array}{l}\text { Type of Covenant } \\
\text { Violated }\end{array}$} & $\begin{array}{l}\text { Financial } \\
\text { (\% of Firms) }\end{array}$ & $\begin{array}{l}\text { Operational } \\
\text { (\% of Firms) }\end{array}$ & $\begin{array}{l}\text { Consequences of } \\
\text { Covenant Violation }\end{array}$ & $\begin{array}{l}\text { Cancellation } \\
\text { (\% of Firms) }\end{array}$ & $\begin{array}{l}\text { Renegotiation } \\
\text { (\% of Firms) }\end{array}$ & $\begin{array}{c}\text { Neither } \\
\text { (\% of Firms) }\end{array}$ \\
\hline & 100.00 & 10.61 & & 10.45 & 53.73 & 35.82 \\
\hline & & & $\begin{array}{l}\text { All Credit Lines } \\
\text { Canceled? (Yes - \%) }\end{array}$ & 9.09 & & \\
\hline
\end{tabular}

Panel C: Renegotiation

Changes in Terms of Credit Line Following Renegotiation

\begin{tabular}{|c|c|c|c|c|}
\hline & Fee \& Markup & Collateral Requirement & Credit Line Size & Credit Line Maturity \\
\hline & $\begin{array}{l}\text { Increased? } \\
\text { (Yes) } \\
\% \text { of Firms }\end{array}$ & $\begin{array}{l}\text { Increased? } \\
\text { (Yes) } \\
\% \text { of Firms }\end{array}$ & $\begin{array}{l}\text { Reduced? } \\
\text { (Yes) } \\
\% \text { of Firms }\end{array}$ & $\begin{array}{l}\text { Reduced? } \\
\text { (Yes) } \\
\% \text { of Firms }\end{array}$ \\
\hline Near Violation & 62.50 & 45.83 & 54.17 & 16.67 \\
\hline Violation & 68.75 & 53.06 & 51.02 & 14.58 \\
\hline
\end{tabular}

Panel D: More Willing to Pay for a "Rainy Day" Credit Line Following Credit Crisis?

\begin{tabular}{lccc}
\hline & $\begin{array}{c}\text { Yes, More Willing to } \\
\text { Pay } \\
\text { (\%) of Firms }\end{array}$ & $\begin{array}{c}\text { Not Willing to Pay, } \\
\text { We Have of Firms }\end{array}$ & $\begin{array}{c}\text { Not Willing to } \\
\text { Pay } \\
\text { (\%) of Firms }\end{array}$ \\
\cline { 2 - 4 } & 45.27 & 22.22 & 32.51 \\
Pay Low Premium & 30.43 & & \\
Pay Medium Premium & 13.56 & \\
Pay High Premium & 1.28 & \\
\hline \hline
\end{tabular}




\section{Table 10 - The Interplay between Cash Holdings and Credit Lines in the Corporate Spending Process}

This table reports OLS and Instrumental Variable (IV) estimation results from planned expenditure regressions. The data are gathered from the 2009Q1 survey. Refer to Table 1 for detailed variable definitions. Test-statistics reported in parentheses are based on heteroskedasticity-consistent standard errors adjusted for clustering across observations of a given industry using the 2-Step GMM estimator. The table also reports diagnostic statistics for instruments' overidentification (Hansen's $J$-stat $p$-values reported) and first-stage $F$-test of excluded instruments (lowest $p$-values reported).

\begin{tabular}{|c|c|c|c|c|c|c|}
\hline & \multicolumn{2}{|c|}{ Planned Investment } & \multicolumn{2}{|c|}{ Planned Tech Spending } & \multicolumn{2}{|c|}{ Planned Employment } \\
\hline & $\begin{array}{c}\text { OLS } \\
(1)\end{array}$ & $\begin{array}{l}\text { IV } \\
(2) \\
\end{array}$ & $\begin{array}{c}\text { OLS } \\
(3) \\
\end{array}$ & $\begin{array}{l}\text { IV } \\
(4)\end{array}$ & $\begin{array}{c}\text { OLS } \\
(5)\end{array}$ & $\begin{array}{l}\text { IV } \\
(6)\end{array}$ \\
\hline Cash Holdings & $\begin{array}{l}-0.136 \\
(-0.52)\end{array}$ & $\begin{array}{c}-0.565^{* *} \\
(-2.14)\end{array}$ & $\begin{array}{l}-0.003 \\
(-0.02)\end{array}$ & $\begin{array}{c}-0.484^{*} \\
(-1.93)\end{array}$ & $\begin{array}{c}-0.552^{* *} \\
(-2.12)\end{array}$ & $\begin{array}{l}-0.170 \\
(-0.51)\end{array}$ \\
\hline Credit Line & $\begin{array}{c}-0.203^{* * *} \\
(-3.43)\end{array}$ & $\begin{array}{c}-0.332 * * * \\
(-3.00)\end{array}$ & $\begin{array}{l}-0.114 \\
(-1.01)\end{array}$ & $\begin{array}{c}-0.219^{* * *} \\
(-2.58)\end{array}$ & $\begin{array}{l}-0.009 \\
(-0.14)\end{array}$ & $\begin{array}{c}-0.125^{*} \\
(-1.73)\end{array}$ \\
\hline Cash Holdings $\times$ Credit Line & $\begin{array}{c}1.127^{*} \\
(1.78)\end{array}$ & $\begin{array}{c}1.814^{* *} \\
(2.53)\end{array}$ & $\begin{array}{l}0.539 \\
(1.19)\end{array}$ & $\begin{array}{c}1.569^{* * *} \\
(2.75)\end{array}$ & $\begin{array}{l}2.665 \\
(1.55)\end{array}$ & $\begin{array}{l}1.438 \\
(0.76)\end{array}$ \\
\hline Large & $\begin{array}{l}0.023 \\
(0.62)\end{array}$ & $\begin{array}{l}0.018 \\
(0.54)\end{array}$ & $\begin{array}{l}0.019 \\
(0.85)\end{array}$ & $\begin{array}{l}0.021 \\
(0.88)\end{array}$ & $\begin{array}{l}0.026 \\
(1.50)\end{array}$ & $\begin{array}{l}0.027 \\
(1.54)\end{array}$ \\
\hline Public Firm & $\begin{array}{l}-0.061 \\
(-1.54)\end{array}$ & $\begin{array}{l}-0.049 \\
(-1.26)\end{array}$ & $\begin{array}{l}-0.112 \\
(-1.23)\end{array}$ & $\begin{array}{l}-0.110 \\
(-1.21)\end{array}$ & $\begin{array}{l}-0.017 \\
(-0.95)\end{array}$ & $\begin{array}{c}-0.030^{*} \\
(-1.94)\end{array}$ \\
\hline Investment Grade & $\begin{array}{l}0.028 \\
(0.84)\end{array}$ & $\begin{array}{l}0.031 \\
(0.97)\end{array}$ & $\begin{array}{l}0.109 \\
(1.09)\end{array}$ & $\begin{array}{l}0.120 \\
(1.17)\end{array}$ & $\begin{array}{l}0.011 \\
(0.58)\end{array}$ & $\begin{array}{l}-0.008 \\
(-0.42)\end{array}$ \\
\hline Easy Access to Credit & $\begin{array}{c}0.081^{* * *} \\
(2.57)\end{array}$ & $\begin{array}{c}0.084^{* * *} \\
(2.74)\end{array}$ & $\begin{array}{c}0.047^{*} \\
(1.73)\end{array}$ & $\begin{array}{c}0.052^{*} \\
(1.94)\end{array}$ & $\begin{array}{c}0.030^{* * *} \\
(3.96)\end{array}$ & $\begin{array}{c}0.024^{* *} \\
(1.99)\end{array}$ \\
\hline Obs. & 215 & 208 & 208 & 203 & 220 & 213 \\
\hline Adj.- $R^{2}$ & 0.033 & 0.016 & 0.037 & 0.022 & 0.142 & 0.071 \\
\hline \multicolumn{7}{|l|}{ Diagnostic Statistics } \\
\hline Hansen's J-Stat. ( $p$-val.) & & 0.618 & & 0.760 & & 0.233 \\
\hline First-Stage $F$-test (lowest $p$-val.) & & $<0.001$ & & $<0.001$ & & $<0.001$ \\
\hline
\end{tabular}

Note: ${ }^{* * *}, * *$ and $*$ indicate statistical significance at the $1 \%, 5 \%$ and $10 \%$ (two-tail) test levels, respectively. 


\section{Table 11 - The Interplay between Cash Holdings and Drawdowns in the Corporate Spending Process}

This table reports OLS estimation results from investment regressions. The data are gathered from the 2009Q1 survey. Refer to Table 1 for detailed variable definitions. Test-statistics reported in parentheses are based on heteroskedasticity-consistent standard errors adjusted for clustering across observations of a given industry.

\begin{tabular}{lccc}
\hline \hline & Planned Investment & Planned Tech Spending & Planned Employment \\
\hline Cash Holdings & $-0.352^{*}$ & $-0.216^{* *}$ & -0.026 \\
& $(-1.74)$ & $(-2.05)$ & $(-0.10)$ \\
Drawdowns & $-0.142^{* * *}$ & $-0.099^{* * *}$ & $-0.077^{* * *}$ \\
& $(-4.49)$ & $(-3.23)$ & $(-3.2)$ \\
Cash Holdings×Drawdowns & $1.416^{* * *}$ & $0.869^{* * *}$ & 0.190 \\
& $(3.01)$ & $(2.83)$ & $(0.46)$ \\
Large & 0.014 & $0.032^{* * *}$ & 0.012 \\
& $(0.34)$ & $(3.35)$ & $(0.35)$ \\
Public Firm & -0.027 & -0.008 & $-0.044^{* *}$ \\
& $(-0.78)$ & $(-0.43)$ & $(-2.36)$ \\
Investment Grade & 0.034 & -0.023 & 0.004 \\
& $(0.66)$ & $(-0.53)$ & $(0.28)$ \\
Easy Access to Credit & $0.123^{* * *}$ & $0.044^{* * *}$ & 0.019 \\
& $(3.72)$ & $(2.99)$ & $(0.83)$ \\
Obs. & 176 & 172 & 181 \\
Adj.- $\mathrm{R}^{2}$ & 0.070 & 0.057 & 0.022 \\
\hline Note: $* * * * *$ and $*$ indicate statistical significance at the $1 \%, 5 \%$ and $10 \%($ two-tail) test levels, respectively.
\end{tabular}

Note: ${ }^{* * *},{ }^{* *}$ and ${ }^{*}$ indicate statistical significance at the $1 \%, 5 \%$ and $10 \%$ (two-tail) test levels, respectively. 
Table 12 - The Interplay between Cash Holdings and Credit Lines in the Investment Process Conditional on Growth Prospects

This table reports Instrumental Variable (IV) estimation results from investment regressions for firms below and above the sample median Investment Growth Prospects. The data are gathered from the 2009Q1 survey. Refer to Table 1 for detailed variable definitions. Test-statistics reported in parentheses are based on heteroskedasticity-consistent standard errors adjusted for clustering across observations of a given industry using the 2-Step GMM estimator. The table also reports diagnostic statistics for instruments' overidentification (Hansen's $J$-stat $p$-values reported) and first-stage $F$-test of excluded instruments (lowest $p$-values reported).

\begin{tabular}{|c|c|c|c|c|}
\hline & \multicolumn{2}{|c|}{$\begin{array}{c}\text { Below Median } \\
\text { Investment Prospects }\end{array}$} & \multicolumn{2}{|c|}{$\begin{array}{c}\text { Above Median } \\
\text { Investment Prospects }\end{array}$} \\
\hline & $\begin{array}{c}\text { OLS } \\
(1)\end{array}$ & $\begin{array}{l}\text { IV } \\
(2)\end{array}$ & $\begin{array}{c}\text { OLS } \\
(3) \\
\end{array}$ & $\begin{array}{l}\text { IV } \\
(4)\end{array}$ \\
\hline Cash Holdings & $\begin{array}{l}0.200 \\
(0.52)\end{array}$ & $\begin{array}{l}-0.272 \\
(-0.83)\end{array}$ & $\begin{array}{c}-0.708^{* *} \\
(-2.45)\end{array}$ & $\begin{array}{l}-0.790 \\
(-1.64)\end{array}$ \\
\hline Credit Line & $\begin{array}{l}0.157 \\
(1.26)\end{array}$ & $\begin{array}{l}-0.102 \\
(-0.49)\end{array}$ & $\begin{array}{c}-0.561^{* * *} \\
(-3.90)\end{array}$ & $\begin{array}{l}-0.461 \\
(-1.55)\end{array}$ \\
\hline Cash Holdings $\times$ Credit Line & $\begin{array}{l}-0.423 \\
(-0.46)\end{array}$ & $\begin{array}{l}0.428 \\
(0.48)\end{array}$ & $\begin{array}{c}3.380^{* * *} \\
(6.76)\end{array}$ & $\begin{array}{c}3.499^{* * *} \\
(2.58)\end{array}$ \\
\hline Large & $\begin{array}{l}0.028 \\
(0.58)\end{array}$ & $\begin{array}{l}0.030 \\
(0.63)\end{array}$ & $\begin{array}{l}0.039 \\
(0.75)\end{array}$ & $\begin{array}{l}0.041 \\
(1.00)\end{array}$ \\
\hline Public Firm & $\begin{array}{l}0.004 \\
(0.05)\end{array}$ & $\begin{array}{l}-0.017 \\
(-0.22)\end{array}$ & $\begin{array}{l}-0.067 \\
(-1.58)\end{array}$ & $\begin{array}{l}-0.053 \\
(-1.17)\end{array}$ \\
\hline Investment Grade & $\begin{array}{l}-0.041 \\
(-0.45)\end{array}$ & $\begin{array}{l}-0.028 \\
(-0.33)\end{array}$ & $\begin{array}{l}0.016 \\
(0.24)\end{array}$ & $\begin{array}{l}0.011 \\
(0.18)\end{array}$ \\
\hline Easy Access to Credit & $\begin{array}{l}-0.020 \\
(-0.35)\end{array}$ & $\begin{array}{l}-0.037 \\
(-0.66)\end{array}$ & $\begin{array}{c}0.107^{* * *} \\
(3.80)\end{array}$ & $\begin{array}{c}0.117^{* * *} \\
(6.07)\end{array}$ \\
\hline Obs. & 102 & 100 & 111 & 106 \\
\hline Adj.- $R^{2}$ & 0.015 & 0.000 & 0.095 & 0.087 \\
\hline \multicolumn{5}{|l|}{ Diagnostic Statistics } \\
\hline Hansen's $J$-Stat. ( $p$-val.) & & 0.934 & & 0.368 \\
\hline First-Stage $F$-test (lowest $p$-val.) & & $<0.001$ & & $<0.001$ \\
\hline
\end{tabular}

Note: ${ }^{* * *},{ }^{* *}$ and ${ }^{*}$ indicate statistical significance at the $1 \%, 5 \%$ and $10 \%$ (two-tail) test levels, respectively. 


\section{Figure 1 - Economic Effect of Internal Liquidity on Credit Lines}

This figure depicts the sensitivity of credit lines to internal liquidity. Panel A shows the percentage change in credit lines [vertical axis] associated with a one-interquartile range (IQR) change in cash flows $(=0.12)$ at different levels of cash holdings [horizontal axis]. Panel B shows the percentage change in credit lines associated with a one-IQR change in cash holdings $(=0.12)$ at different levels of cash flows.

Panel A - Sensitivity of Credit Lines to 1 IQR Change in Cash Flows at Different Levels of Cash Holdings

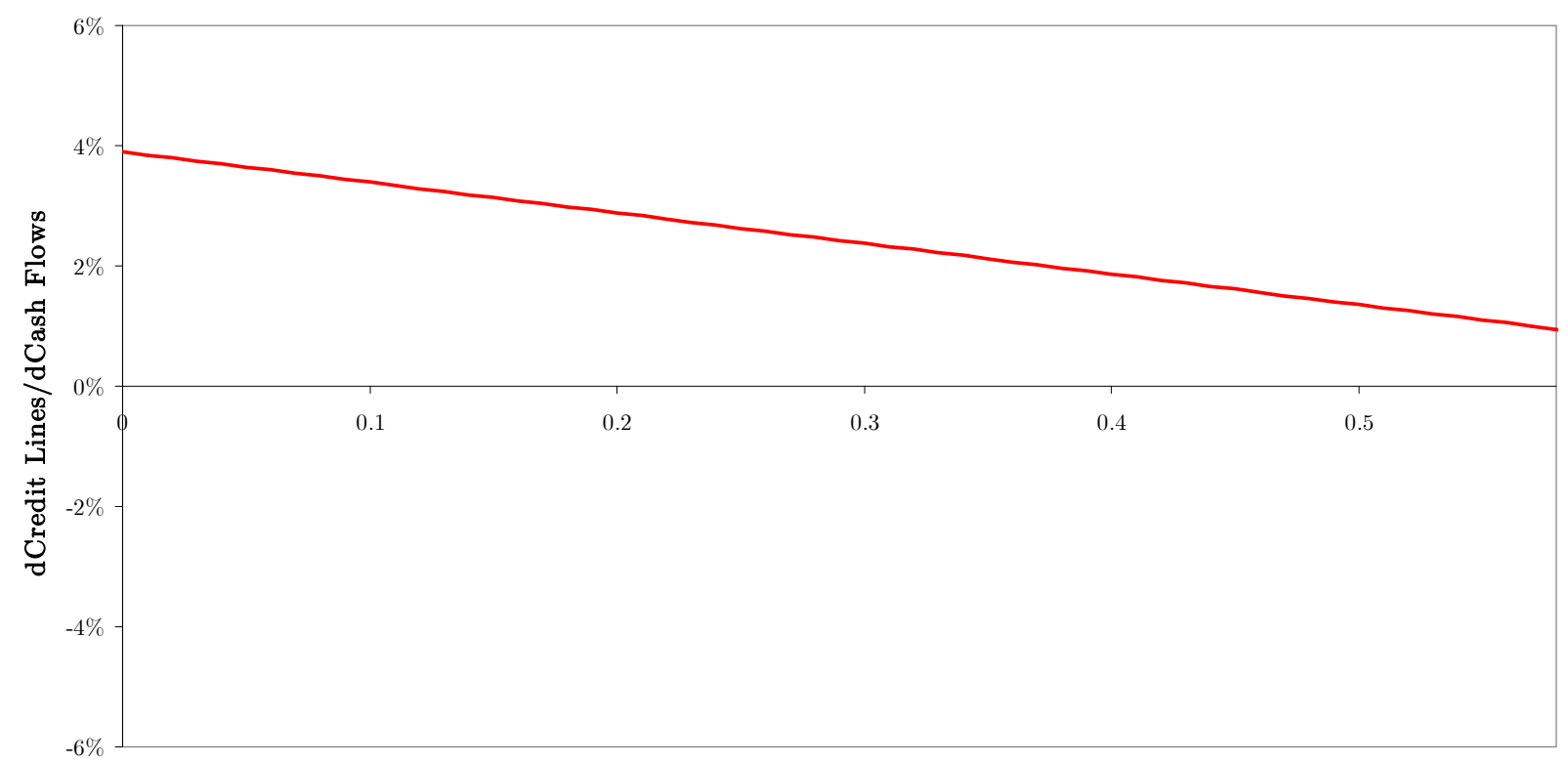

Cash Holdings/Total Assets

— Economic Effect of Cash Holdings on Credit Lines

Panel B - Sensitivity of Credit Lines to 1 IQR Change in Cash Holdings at Different Levels of Cash Flows

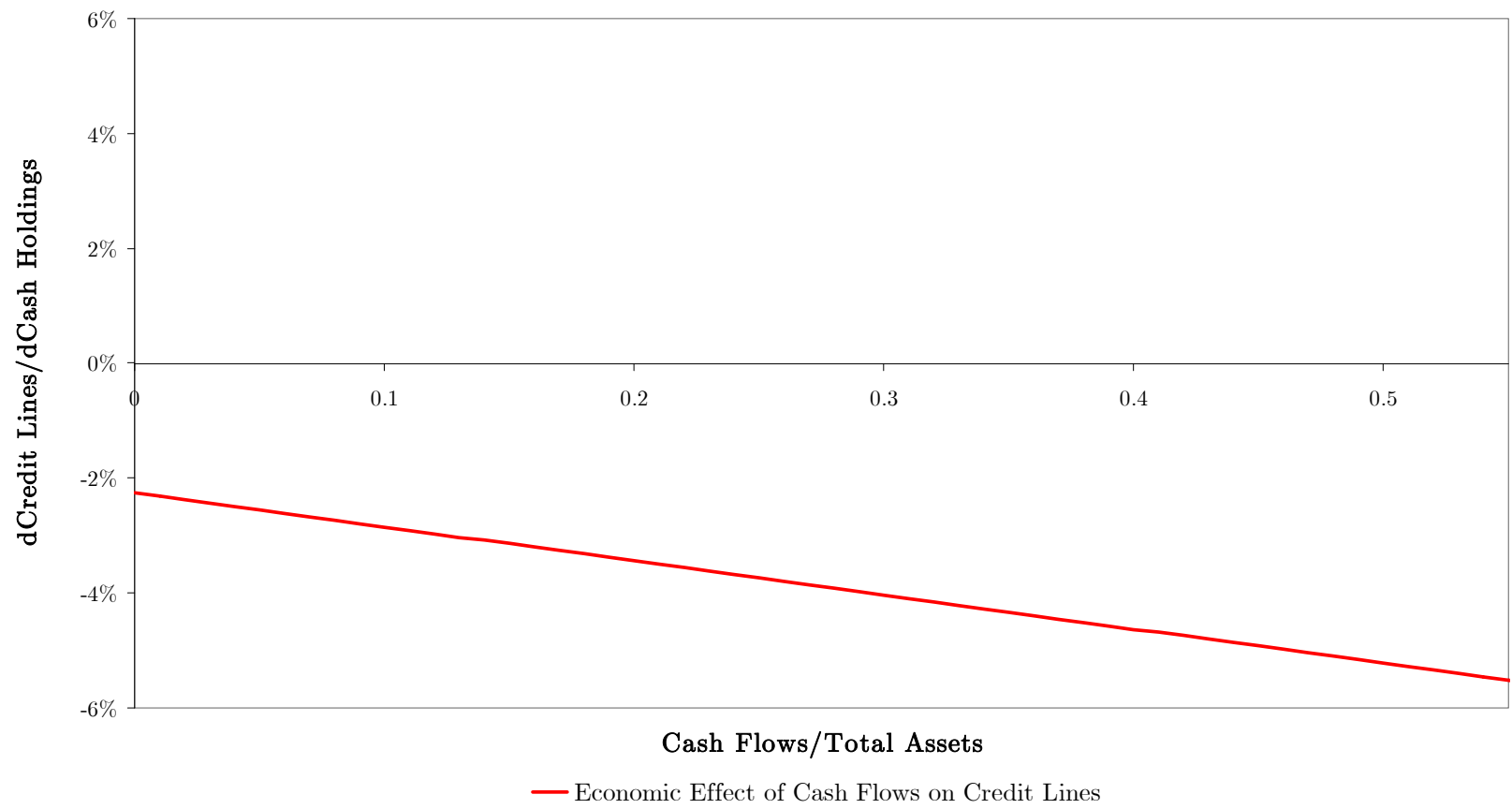




\section{Figure 2 - Economic Effect of Liquidity on Investment}

This figure depicts the sensitivity of planned investment to liquidity. Panel A shows the percentage change in investment [vertical axis] associated with a one-interquartile range (IQR) change in lines of credit $(=0.23)$ at different levels of cash holdings [horizontal axis]. Panel B shows the percentage change in investment associated with a one-IQR change in cash holdings $(=0.10)$ at different levels of credit lines.

Panel A - Sensitivity of Investment to 1 IQR Change in Credit Linesat Different Levels of Cash Holdings

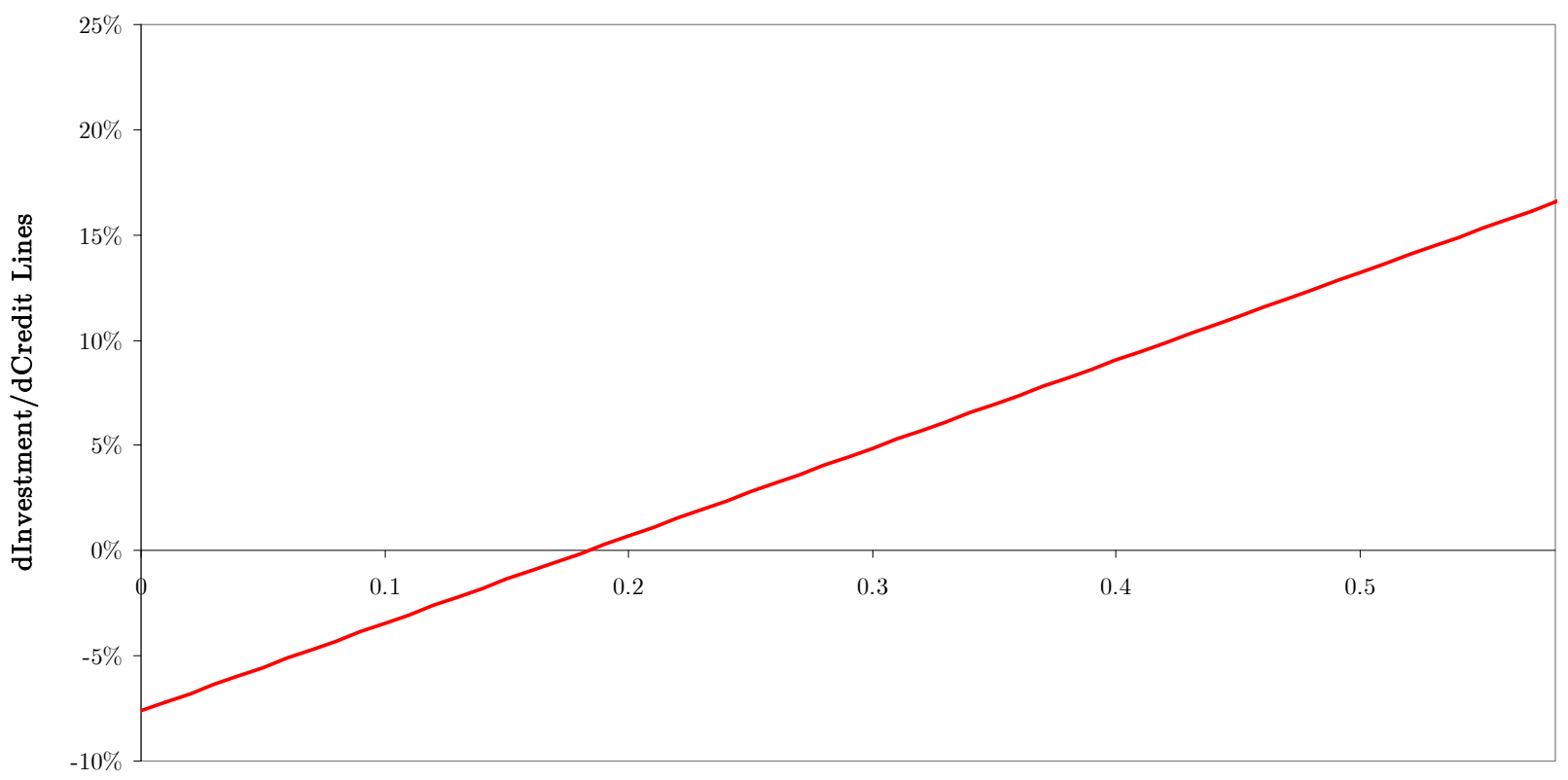

Cash Holdings/Total Assets

— Economic Effect of Cash Holdings on Investment

Panel B - Sensitivity of Investment to 1 IQR Change in Cash Holdings at Different Levels of Credit Lines

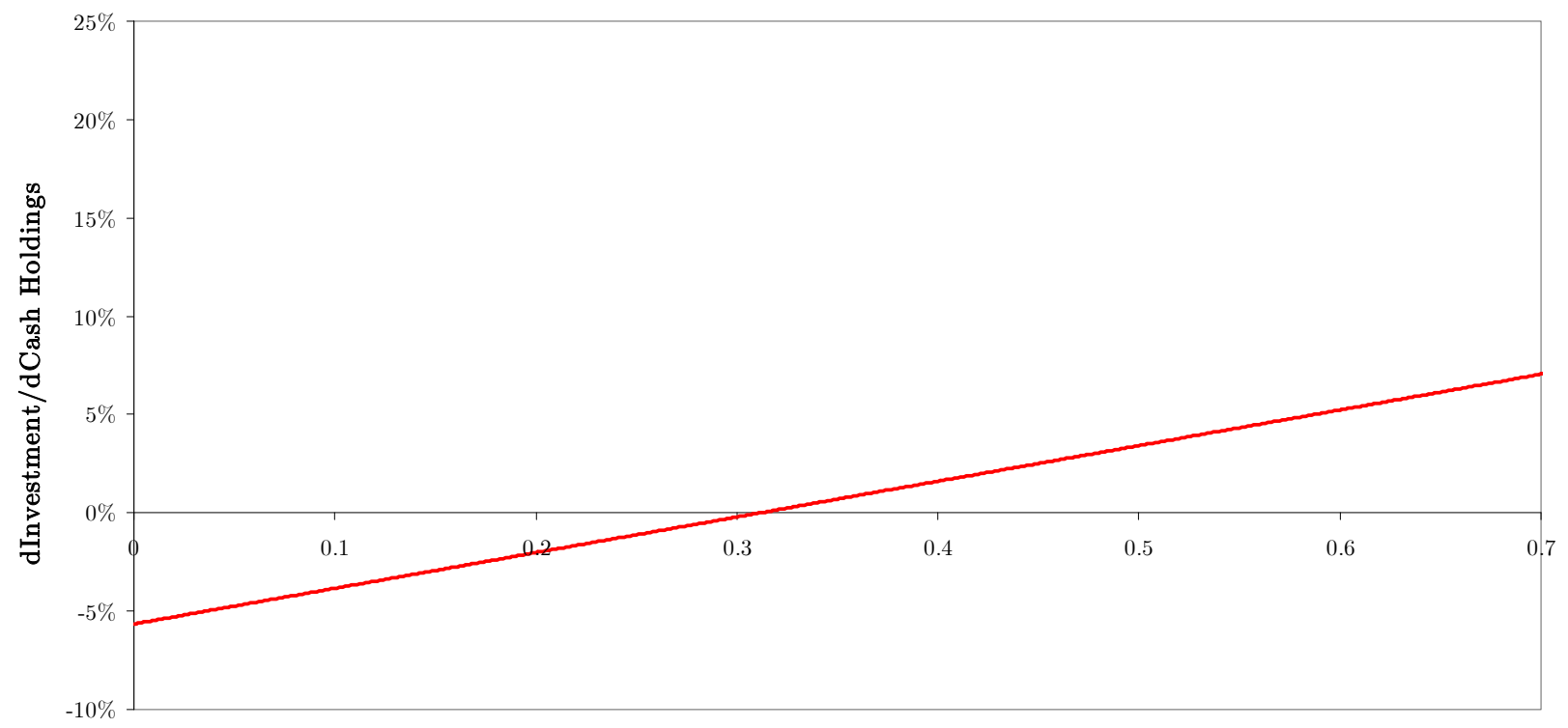

Credit Lines/Total Assets

—Economic Effect of Credit Lines on Investment 


\section{Figure 3 - Economic Effect of Liquidity on Investment by Growth Prospects}

This figure depicts the sensitivity of planned investment to liquidity for firms with low and high growth prospects. The solid line shows the percentage change in investment [vertical axis] associated with a one-interquartile range (IQR) change in cash holdings $(=0.10)$ at different levels of credit lines [horizontal axis] for firms in the bottom five deciles of the distribution of CFO self-reported long-term prospects ("Low Growth Prospects"). The dashed line shows the percentage change in investment associated with a one-IQR change in cash holdings $(=0.10)$ at different levels of credit lines for firms in the top five deciles of the distribution of CFO self-reported long-term prospects ("High Growth Prospects").

Sensitivity of Investment to 1 IQR Change in Cash Holdings at Different Levels of Credit Lines - Low vs. High Growth Prospects

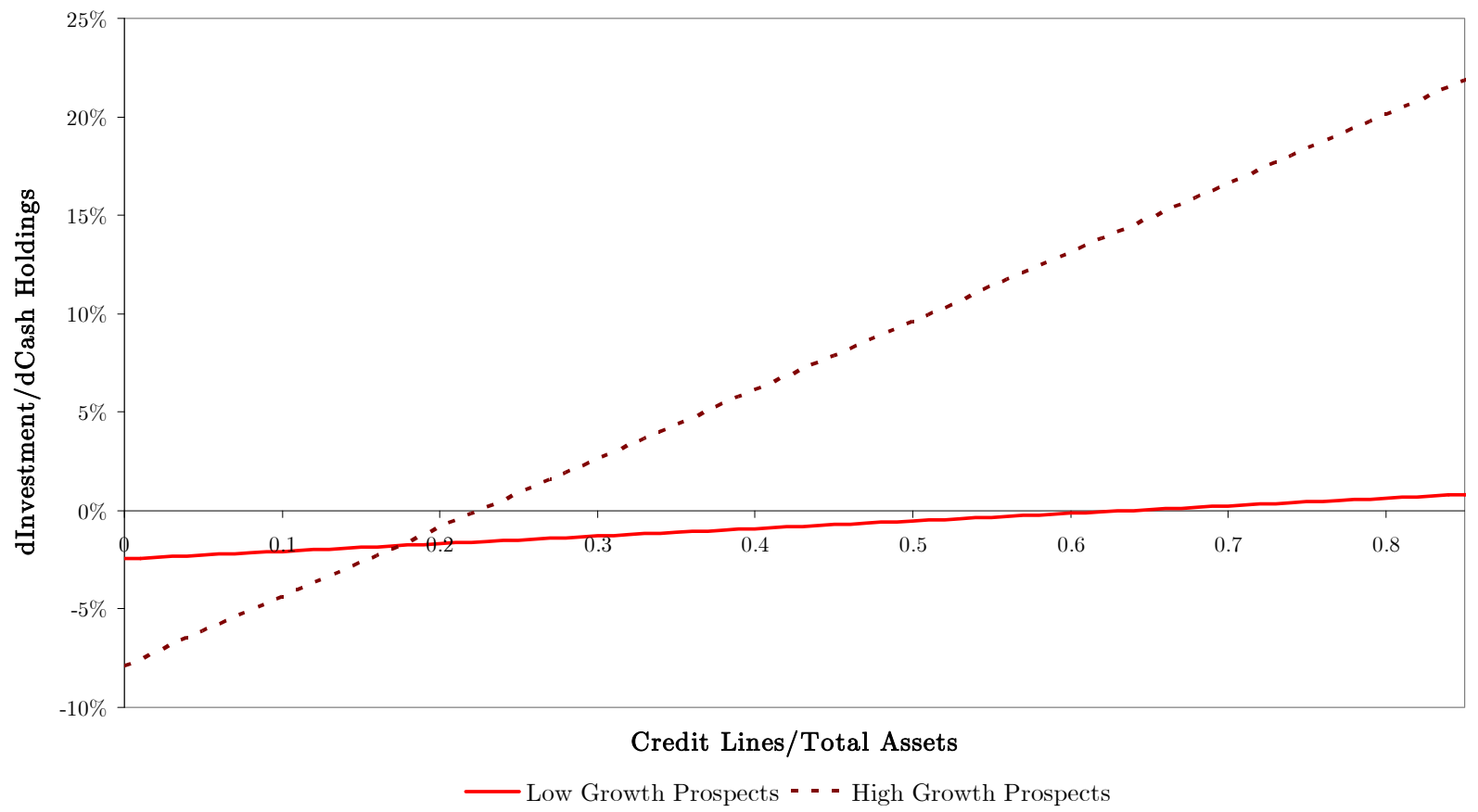




\section{Appendix}

\section{Table A1 - Survey and COMPUSTAT Samples}

This table compares public firms in the CFO survey sample with active firms in the COMPUSTAT database as of 2009Q1. We report the number of observations and percentages based on several firm characteristics. We also report basic descriptive statistics on cash holdings for the two samples. We include all firms with the exception of financial, governmental, and nonprofit organizations. Firms are defined as Small if their sales are less than $\$ 1$ billion, and Large otherwise. Non-Investment Grade firms are unrated or rated below BBB-. Investment Grade firms are those with a credit rating BBB- or higher. Cash Holdings is the ratio of cash holdings and marketable securities to total assets. Cash Flow is return on assets.

\begin{tabular}{|c|c|c|c|c|}
\hline \multirow[t]{2}{*}{ Firm Types } & \multicolumn{2}{|c|}{ Survey Sample } & \multicolumn{2}{|c|}{ COMPUSTAT Sample } \\
\hline & Obs. $(\mathrm{N})$ & Freq. (\%) & Obs. $(\mathrm{N})$ & Freq. (\%) \\
\hline Small & 41 & $47 \%$ & 3,647 & $68 \%$ \\
\hline Large & 46 & $53 \%$ & 1,698 & $32 \%$ \\
\hline Non-Investment Grade & 54 & $62 \%$ & 997 & $52 \%$ \\
\hline Investment Grade & 33 & $38 \%$ & 907 & $48 \%$ \\
\hline Non-Dividend Payer & 46 & $53 \%$ & 2,667 & $55 \%$ \\
\hline Dividend Payer & 41 & $47 \%$ & 2,173 & $45 \%$ \\
\hline Unprofitable & 11 & $16 \%$ & 1,152 & $23 \%$ \\
\hline \multirow[t]{2}{*}{ Profitable } & 58 & $84 \%$ & 3,875 & $77 \%$ \\
\hline & Mean & Median & Mean & Median \\
\hline Cash Holdings & 0.146 & 0.071 & 0.178 & 0.078 \\
\hline Cash Flow & 0.076 & 0.080 & 0.044 & 0.082 \\
\hline
\end{tabular}

